\title{
Farmland Rental Rates: Does Organic Certification Matter? ॰ ๘
}

Kate Binzen Fuller Associate professor and extension specialist, Department of Agricultural Economics and Economics, Montana State University, Bozeman; kate.fuller@montana.edu

Joseph P. Janzen Assistant professor, Department of Agricultural and Consumer Economics, University of Illinois, Urbana-Champaign; jjanzen@illinois.edu

B. Munkhnasan Economist, Research and Statistics Division, Bank of Mongolia, Ulaanbaatar; munkhnasan.b@mongolbank.mn

\begin{abstract}
We estimate U.S. organic farmers' marginal willingness to pay to rent an acre of certified organic land relative to conventional farmland. Using a selection-on-observables design and farm-level data on farmland rental rates, organic status, and many conditioning variables, we address the role of profitability in mediating the effect of organic status. We find a $26 \%$ rental rate premium for organic farmland not driven by higher profits on organic farms. This premium is a modest incentive for landowners but a barrier for tenants to convert to organic farming practices, which may explain limited growth in U.S. organic acreage. (JEL Q11, Q15)
\end{abstract}

\section{Introduction}

Demand for organic food has led a growing number of farms to adopt certified organic production practices. In 2016, 2.7 million acres of farmland were used to produce certified organic crops in the United States. Although these are less than $1 \%$ of total U.S. cropland, current organic acreage is the result of $2.5 \%$ year-over-year growth from 2008 to 2016 (National Agricultural Statistics Service 2017). Growth in U.S. organic acreage has lagged growth in the value of organic production and retail sales. Over the same period, the value of U.S. organic crop production and retail food sales both grew by about $10 \%$ annually (Organic Trade Association 2016; National Agricultural Statistics Service 2017).

Land Economics • February 2021 • 97 (1): 80-106 ISSN 0023-7639; E-ISSN 1543-8325

(C) 2021 by the Board of Regents of the

University of Wisconsin System
Potential explanations for faster growth in the value of organic production relative to acreage include the allocation of organic acres to higher-value crops, organic crop yield growth, and increasing price premiums for organic crops (Oberholtzer, Dimitri, and Greene 2005; McBride et al. 2015).

Growth in organic acreage is partly constrained by the organic certification process. Cropland must be farmed according to organic production practices that forbid the use of synthetic fertilizers and pesticides for three years before production can be labeled for sale as organic. This constraint implies land that can produce certified organic crops will be in limited supply in the short run. The combination of higher-value crops, output price premiums, and inelastic farmland supply may generate economic rents that are bid into input prices, so that organic land will be priced at a premium to conventional land. In aggregate, data on U.S. farms appear to bear this out. The USDA Agricultural Resource Management Surveys (ARMS) conducted between 2003 and 2011 showed median cash rental rates paid by organic farms for cropland were $23 \%$ higher than rental rates paid by conventional farms. Median reported cropland values were $26 \%$ higher for organic farms.

Although there is an extensive literature on the value of farmland and the myriad characteristics that give it value (e.g., Palmquist 1989; Plantinga, Lubowski, and Stavins 2002; Borchers, Ifft, and Kuethe 2014; Severen, Costello, and Deschênes 2018), no study has attempted to estimate the value of organic land. ${ }^{1}$ Aggregate differences in rental rates

\footnotetext{
${ }^{1}$ Technically, the output is certified organic, not the land itself. However, we and others such as the USDA National
} 
and land values between organic and conventional farms could be the result of systematic differences between the types of land in the distribution of soil productivity, distance to output markets, or other factors, rather than certification. For example, California has the most organic cropland acres and the most expensive farmland in the United States. But this relationship could be driven by the productivity of California land and the high value of the fruit and vegetable crops grown there, along with greater demand for organic versions of those crops relative to field crops like wheat, corn, and soybeans predominant in other parts of the country.

To identify the value of organic certification in the farmland market, we use the ARMS, a comprehensive, repeated cross-section survey of U.S. farms, and a selection-on-observables research design to estimate organic farmers' marginal willingness to rent an acre of organic land relative to similar conventional farmland. This regression model expresses the average per-acre rental rate paid by the farm as a function of the proportion of the farm's acres certified as organic and other covariates. We carefully consider the identification and interpretation of this organic effect given the limitations of our data. Without the ability to use farm-level fixed effects, observe farmers' profit expectations, or adjust for farm-specific soil quality, identification requires that farm-specific deviations from local average soil quality, management ability, and other unobserved determinants of willingness to pay for cropland are uncorrelated with the farm's organic status.

We specifically address the potential role of profit differences across farms in mediating the relationship between organic status and farmland rental rates by estimating the controlled direct effect (CDE) (Acharya, Blackwell, and Sen 2016) of organic status on rental rates. The CDE separates the observed effect of organic status on farmland rental rates into components related to a specific mechanism, in our case accounting profits, and other factors. In short, we find positive significant differences in rental rates for organic and con-

Agricultural Statistics Service refer to land used for producing certified organic crops as "organic land." ventional cropland for which profitability does not appear to be the mechanism through which the land market effect operates. Instead, the rental rate premium represents a modest return to the landowner for organic conversion.

An empirical estimate of the willingness to pay for use of organic land is relevant to two areas of existing research on the economics of organic agriculture. First, higher rental rates for organic land may provide evidence in the unresolved debate on the relative profitability of organic agriculture. Higher organic land prices could be explained by economic rents created by organic conversion and priced into organic input markets. The existence of such rents is the subject of considerable debate, and previous comparisons of organic and conventional profits have produced mixed results. For most crops, comparisons of output prices, yields, and production costs between these systems suggest that organic production has higher prices and costs and lower yields. Therefore, the net effect of organic conversion on profit is ambiguous. In a high-profile meta-analysis of organic profitability, Crowder and Reganold (2015) found that organic price premiums more than offset the yield and cost disadvantage of organic production systems across a wide range of crops and geographies. Others contradict this finding, especially in observational (rather than experimental) studies (e.g., Uematsu and Mishra 2012).

Defining the relevant measure of profit in organic-conventional profitability comparisons is difficult because observed accounting profits and unobserved economic profits are not the same. In aggregate, competitive markets adjust so that economic profits are bid into factor prices. We assess the economic profits generated by organic farming by considering the most important factor price for production agriculture: the per-period price of farmland, which is the cash rental rate. If there are permanent and economically meaningful differences in profit for organic agriculture, these differences should affect factor prices, especially for relatively fixed factors like land. Moreover, rental rates are related to expectations about profitability that do not experience the same year-to-year fluctuations as do accounting profits. Single-season com- 
parisons of net farm income for crop farms are confounded by weather-driven variation in profitability that could wrongly be attributed to other factors. Although collecting significantly lengthy panel data could eliminate or ameliorate this concern, no large farm-scale data of this type exist with a significant number of organic farms, making organic-conventional comparisons difficult in practice. Thus, examining rental rates paid by organic and conventional farms may be informative about the net effect of organic conversion on profitability and whether any resulting economic rents are captured by landowners or other input suppliers.

Second, examining economic profit as a mechanism by which organic conversion may affect rental rates may help explain farmers' motivations for organic conversion. There is a lengthy literature examining whether pecuniary or nonpecuniary benefits and costs motivate farmers to adopt organic production practices. Nonpecuniary motives may be related to perceived environmental, personal, social, ideological, or philosophical benefits and costs (Sierra et al. 2008). If organic farmers are found to bid up the price of organic land and this behavior is related to observed accounting profits, this is strong evidence based on market behavior for an economic motive for conversion that may corroborate or counter conclusions based on stated preferences.

More broadly, measuring the input market response to organic conversion helps us understand the consequences of existing and future conversion for different parties with an interest in farmland. Understanding the market value of organic land is important for farmers, landowners, and the brokers and appraisers who facilitate the efficient exchange of farmland. These actors need to assess the likely consequences of future conversion. Recently, a number of investment funds and organic food processors have purchased large tracts of farmland for conversion to organic production on the premise that they can earn economic profits and enhance the value of the land (Karnowski 2018; Farmland LP 2019). Access to farmland is often cited as an important barrier to entry for new farmers, and beginning farms often are smaller than established farms (Ahearn 2013). Small farms, especially capital-constrained younger and beginning farmers, may be more likely to transition to organic (Delbridge and King 2016). In these cases, if the economic rents associated with organic agriculture are bid into rental rates and capitalized in land values, farmers will only benefit to the extent that they own already farmland. Farmland acquisition will remain a significant barrier to entry. Therefore, organic conversion may not be a cost-effective means to achieve multiple objectives related to farmer welfare, environmental goods and services, and consumer food demand.

Our assessment of the value of organic certification in the rental market for farmland relies on comparisons between organic and conventional farms. We briefly describe these differences, how they have motivated other research on organic agriculture, and how our study fits into this literature. Our analysis overcomes many of the difficulties in this earlier work by using a large-scale, nationally representative survey of farms conducted by the USDA. We describe regressions to estimate the organic effect, the important observable conditioning variables, and those observed and unobserved factors that cannot or should not enter the regression model.

We discuss the conditions under which we can interpret the estimated effect of organic status as causal. Econometric estimation of the organic effect in the farmland market is complicated by the small number of organic farms in the United States and the considerable heterogeneity of U.S. farms. We rely mainly on a large, national survey of farmlevel financial information to give us adequate power to overcome these problems. We review a method for assessing the role of observed profits in mediating the effect we observe. Finally, we present our results and suggest a number of policy implications and directions for further research to improve the robustness of our findings.

\section{Why Organic?}

Organic cropland is the result of a certification decision made by farmers and landowners. This decision can be likened to other improve- 
ments made to farmland. such as investments in drainage, where the farmer chooses a production technology with uncertain future payments. Because the improvement is tied to the land, in the sense that control and use of the land is necessary to receive the benefits generated by the investment, the investment should affect the land value. Although this decision is relevant to all farmers and landowners, there is growing evidence that financial investors see organic cropland as having value. Purchasing conventionally farmed land, converting it to organic, and then leasing it out to farmers is the investment strategy of several firms. For example, Farmland LP is an investment fund whose stated goal is to "buy commodity farmland and add value by securing organic certification, investing in infrastructure, and increasing crop diversity." They also state that their "management increases the land's value and enhances the environment" (Farmland LP 2019). Organic food manufacturers have also sought farmland to procure more organic ingredients. General Mills announced a deal to convert a 34,000-acre farm in South Dakota to organic in an effort to secure sufficient organic wheat to produce its Annie's Macaroni and Cheese products (Karnowski 2018).

Many existing economic comparisons of organic and conventional cropping systems are based on data from long-run experimental trials. For example, most studies included in the meta-analysis of Crowder and Reganold (2015) used experimental data. In these trials, researchers replicate conventional and organic production of a given crop in the context of a long-run crop rotation with input use, rotation crops, and other parameters determined by the researcher. The economic portion of these studies carefully measure differences in input use and crop yield, use assumed prices to value crop revenues and input costs, and compare calculated profits (e.g., Delate et al. 2003; Delbridge et al. 2013).

Because output prices are identical across observations in these studies within a treatment group (organic versus conventional), researchers often assess the "benefit" of organic price premiums by comparing calculated profits at organic and conventional price levels. For example, this allowed Crowder and
Reganold (2015) to attribute their finding of higher organic profitability to these premiums.

The external validity of experimental organic-conventional economic comparisons depend on the degree to which management decisions made by the researcher at the outset of the experiment match the ongoing management decisions made by farmers at various points in the rotation's production cycle in response to the changing set of equilibrium prices. While organic treatments are subject to known constraints on input use imposed by certification (particularly prohibitions on synthetic fertilizers, pesticides, and genetically modified organisms) the constraints of the experiment do not allow the researcher to adjust these cropping systems to changing market conditions that may not be common across all farms. In general, the weakness of these experimental studies is that they do not account for these market and farm adjustments.

Organic-conventional cropping systems comparisons based on observational data may have greater external validity. The limited number of existing studies in this vein use relatively small cross-sectional samples of farms and rely on propensity score matching or other selection-on-observables methods to make comparisons. Small samples are largely unavoidable given the relatively small number of organic farms in the United States and elsewhere. For example, Uematsu and Mishra (2012) use the ARMS to compare 65 organic farms to a larger group of conventional farms. They find organic farms do not earn higher profits. McBride and Greene (2009) and McBride et al. (2015) make comparisons from ARMS data for specific years where organic crop farms growing corn, wheat, or soybeans were oversampled to help improve statistical power. They find significant profit differences for organic corn and soybeans but not wheat using samples of approximately 200 organic farmers. Outside the United States, Krause and Machek (2017) find significant profit differences for 291 Czech organic farms but do not exploit the availability of panel data to control for time-invariant unobservables. Froehlich, Melo, and Sampaio (2018) generated a much larger sample of organic farms using the 2008 Brazilian Agriculture Census, which contains approximately 75,000 organic family farms 
(of which only $5 \%$ are certified). They do not find significant differences in profitability between organic and conventional farms in spite of their larger sample. However, they do not explicitly consider the effect of organic certification on profitability, so it is difficult to assess the external validity of their result.

\section{Conversion Decisions}

The validity of observational comparisons relies crucially on the relevance of an available counterfactual. Because the ideal control group of conventional farms would look like observed organic farms in a parallel universe where those farms did not convert to organic, it is important to understand the certification process and the incentives facing farms who certify as organic. Once a farm manager chooses to certify, there is a 36-month transition period during which the USDA National Organic Program regulations require that land must be farmed according to organic practices but production cannot be sold as organic. During this time, farms incur the costs of organic farming-generally lower yields and higher production costs-without augmenting revenue through the organic price premium. The transition period creates a lag between the conversion decision and subsequent market adjustments related to input and output prices. Moreover, the lag generates rigidity in the land market, so we can rule out reverse causality - more land cannot be converted immediately in response to higher organic profit.

An extensive but inconclusive literature on the certification decision suggests motives for certification are heterogeneous; both economic and noneconomic motives affect certification (Darnhofer, Schneeberger, and Freyer 2005; Chouinard et al. 2008; Cranfield, Henson, and Holliday 2010; Kallas, Serra, and Gil 2010; Khaledi et al. 2010; Peterson et al. 2012; Veldstra, Alexander, and Marshall 2014; Trujillo-Barrera, Pennings, and Hofenk 2016). Government programs, the establishment of which may be exogenous to farmlevel conversion decisions, provide extremely limited incentive to undergo organic certification. The magnitude of program funding is so small that government programs are unlikely to be a major driver of observed adoption. For example, the USDA National Organic Certification Cost Sharing Program and Agricultural Management Assistance are help defray some of the costs of the certification process, but payments are capped at $\$ 750$ per farm. Other government programs providing subsidies for conservation practices, such as the Conservation Security/Stewardship Program (CSP) and the Environmental Quality Incentives Program, provide incentives to adopt organic practices. These programs provide payments for conservation practices that may include management methods for an organic cropping system, although organic certification is not necessary to receive payments. In practice, these programs do not appear to have materially affected organic adoption. For example, Kuminoff and Wossink (2010, 240) suggest that although U.S. agricultural policy has "evolved in ways that have favored organic farmers," specific policy measures such as the introduction of the CSP were too small in economic size and geographic scope to have generated a significant exogenous shift in the prevalence of organic cropland acres.

\section{Agricultural Resource Management Survey Dataset}

To examine the relationship between organic agriculture, farm profitability, and farmland prices, we primarily use data from the farmlevel ARMS. To draw meaningful inference in comparisons of organic and conventional cropland, we need a large sample. Finding one is difficult because there are relatively few organic farms and relatively little organic cropland in the United States, even in regions where organic farming is more popular. Since the mid-1990s, the ARMS has annually surveyed a sample of approximately 20,000 farm operations. This is a far larger and more frequent sample than any other existing data source. The ARMS asks the same questions of organic and conventional farms. Other data on organic farm finances, such as the USDA Certified Organic Survey, collect data on organic farms only, so comparisons with conventional agriculture are not feasible. 
Our analysis uses ARMS phase 3 data, which focus on characteristics of the farm business and the farm operator's household. This includes accounting and financial information on revenues, costs, assets, and liabilities. Other survey questions address business and financial decision making, use of crop insurance and government subsidies, off-farm income, and demographic information. The ARMS sampling procedure ensures the data are nationally and regionally representative of the population of U.S. farms with respect to the distribution of farm size and commodities produced (though the survey sample may not be representative of all subgroups, for example, U.S. organic farms). Each farm-level observation includes a sampling weight equal to the probability that such a farm would be included in the survey sample. The weights can be used to estimate population-representative summary statistics (Economic Research Service 2017).

There are two major weaknesses of the ARMS. First, it is a repeated cross-section. It does not intentionally survey the same farms in multiple years. Instead, the entire population of farms is resampled with replacement each year, so most econometric methods for panel data cannot be applied to the ARMS. ${ }^{2}$ Second, the set of questions asked in the ARMS is not constant each year. The majority of questions are stable, but phrasing may change slightly. Select questions asked for research purposes change over time and can move on and off of the survey. For our analysis, we rely on a specific question about the amount of acreage of organic land only asked from 2003 to 2011. During that time, the ARMS contained this question: "Of the total acres in this operation, how many acres were used to harvest certified organic crops?" (Economic Research Service 2018). Because we are only able to identify organic farms via this question, we limit our analysis to these years only.

\footnotetext{
${ }^{2}$ Some researchers (e.g., Weber, Key, and O'Donoghue 2016) have been able to create panel data from ARMS using farms observed at least twice over the survey's relatively long history. In our application to organic farms, using only farms observed at least twice would dramatically reduce sample size and power.
}

\section{Comparing Organic and Conventional Farms in the Agricultural Resource Management Survey}

In the nine-year period for which we consider ARMS data, there are 184,315 farm-level observations. Of these, 4,039 are farms with some positive number of certified organic harvested acres in the survey year. For brevity, we call these organic farms. Although the ARMS is designed to be nationally representative of the population of U.S. farms, organic farms in the ARMS under this definition are only a random sample of organic farms. Conventional farms in the ARMS are not designed to be a suitable control or comparison group for these organic farms.

Because we are looking to make meaningful comparisons of farmland rental rates for organic and conventional farms, we limit the sample for our analysis as follows. We eliminate farms that produced less than $\$ 5,000$ of crops in the survey year, because this is the threshold at which farms must certify if they sell their output as organic. We remove farms if the largest portion of their sales is from livestock, woody trees, or nursery crops. These are farms for which cropland is not a significant input. ${ }^{3}$

The distribution of most farm-level peracre financial variables is strongly rightskewed. Because we make comparisons of per-acre dollar values across farms, we are sensitive to outliers created when reported cropland or rented cropland acres are very low. To mitigate this concern, we winsorize variables measured in dollars per acre at the 99th percentile and explore the role of highper-acre-value farms in influencing our results (in Section 5). ${ }^{4}$ Following these changes, we

\footnotetext{
${ }^{3}$ After excluding primarily livestock farms, farms in our sample may have still have some livestock production and observed revenues and costs per cropland acre may be biased by including livestock-related receipts and expenses. We find such errors are likely to be small since average livestock-related expenses (such as livestock purchases and feed costs) for farms in our sample are approximately $\$ 6$ per cropland acre and the median farm reports no such expenses.

${ }^{4}$ Similar controls for outliers are common in analyses of farm-level survey data (e.g., Roberts, Kirwan, and Hopkins 2003; Kirwan 2009; Goodwin, Mishra, and Ortalo-Magne 2011).
} 
have 73,608 observations, of which 2,051 have some organic acres.

We make two final sample adjustments to facilitate our analysis. First, we limit our sample to farms that cash rent land (that is, farms renting at least some land for which they pay the landlord a fixed rental payment). Cash rental rates are preferable as a measure of the current price of land in our application for several reasons. As per-period prices, rental rates respond primarily to changes in current expected returns, rather than changes in expectations about long-run returns, discount rates, or the option value of nonagricultural land uses (Kirwan 2009). This reduces the set of unobservables that would confound our selection-on-observables research design (described in Section 4). Rental rates may also be more reliably measured in the ARMS than land values. Since only a small share of U.S. farmland changes hands in a given year, farms surveyed by the ARMS self-report an estimated value of their land. Although farmers may estimate land values with relative accuracy (Bigelow, Ifft, and Kuethe 2018), rental payments represent the result of an actual transaction, which may be reported more accurately.

Second, we drop farms located in National Agricultural Statistics Service crop reporting districts (CRDs) where the ARMS survey contains no organic farms so we can estimate CRD fixed effects. There are 181 such CRDs. Comparisons of organic and conventional farms require both farm types in all locations (otherwise average outcomes are subsumed in the CRD-specific fixed effect). These districts group counties in a state by geography, climate, and cropping practices. U.S. states contain between 1 district (as in many small Northeastern states) and 15 (as in Texas). Most major crop-producing states have seven to nine districts. Dropping noncash-renting farms eliminates 28,683 observations, and dropping nonorganic CRDs removes another 7,390 observations from our data.

In our estimation sample, we have 37,535 observations, of which 1,051 have organic acres. It is an oversimplification to consider these two groups as treatment and control. Because any single farm operation may grow both conventional and organic crops, the
Figure 1

Distribution of Organic Status for Farms with Some Organic Acres

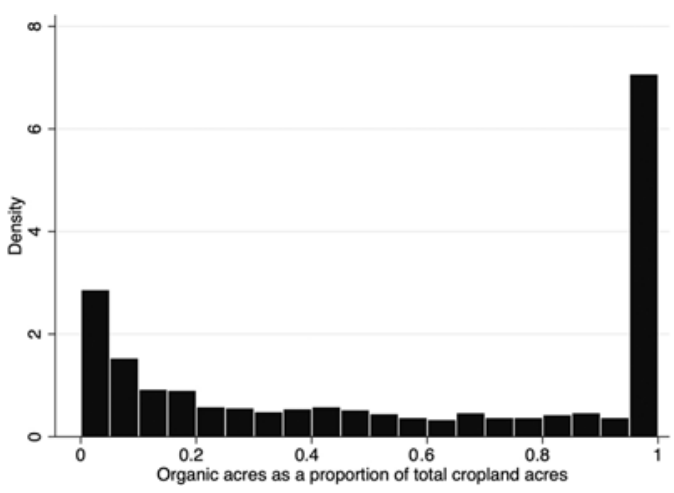

"treatment" of organic certification is not binary at the farm level. We define the organic status of farm $i$ in CRD $j$ at year $t$, Org $_{i j t}$ as the ratio of certified organic crop acres to total cropland acres:

Org $_{i j t}=\frac{\text { Organic Cropland Acres }}{\text { Total Cropland Acres }}$.

Only $2.8 \%$ of the farms in our sample have any organic cropland acres. Of the farms with any organic acreage, growing both organic and conventional crops is fairly common. Figure 1 displays the distribution of organic status on these farms. Approximately one-third of the farms with any organic cropland certify all of their crop acres. The remaining farms exhibit widely varying degrees of certification with a cluster of farms certifying only a small portion $(<20 \%)$ of their cropland.

\section{Other Farm-Level Variables in the Agricultural Resource Management Survey}

We retrieve cropland rental rates paid, cropland values, revenues, costs, subsidy receipts, and other farm characteristics that may differentially affect organic and conventional farms' willingness to pay for farmland, from the ARMS. We summarize these variables in Table 1 for all farms, conventional farms, and organic farms. In general, summary statistics suggest there is considerable within-group heterogeneity and many statistically signifi- 
Table 1

Summary Statistics for Farm-Level Variables in the ARMS by Organic Status, 2003-2011

\begin{tabular}{|c|c|c|c|c|c|c|c|}
\hline \multirow[b]{2}{*}{$\$ 1,000 /$ Farm } & \multicolumn{2}{|c|}{ Total Sample } & \multicolumn{2}{|c|}{ Conventional } & \multicolumn{2}{|c|}{ Organic } & \\
\hline & Mean & St. Dev. & Mean & St. Dev & Mean & St. Dev. & \\
\hline Production revenue & 393 & 695 & 388 & 675 & 714 & 1,543 & $* * *$ \\
\hline Variable costs & 224 & 420 & 220 & 405 & 487 & 1,010 & $* * *$ \\
\hline Fixed costs & 73 & 108 & 73 & 106 & 102 & 184 & $* * *$ \\
\hline ROVC & 165 & 369 & 165 & 354 & 184 & 985 & \\
\hline
\end{tabular}

$\$$ Acre

\begin{tabular}{|c|c|c|c|c|c|c|c|}
\hline Land rental rate & 112 & 114 & 110 & 108 & 253 & 294 & $* * *$ \\
\hline Value of rented land & 4,119 & 4,576 & 4,053 & 4,416 & 8,934 & 10,113 & $* * *$ \\
\hline Production revenue & 658 & 1,307 & 626 & 1,193 & 2,964 & 4,138 & $* * *$ \\
\hline Variable costs & 409 & 887 & 387 & 812 & 2,001 & 2,749 & $* * *$ \\
\hline Fixed costs & 127 & 218 & 124 & 206 & 385 & 617 & $* * *$ \\
\hline ROVC & 251 & 646 & 240 & 592 & 1,045 & 2,166 & $* * *$ \\
\hline Livestock expenses & 6 & 23 & 6 & 23 & 15 & 39 & $*$ \\
\hline Crop insurance revenue & 9 & 26 & 9 & 26 & 10 & 32 & \\
\hline Subsidy receipts & 19 & 21 & 19 & 21 & 16 & 30 & \\
\hline Off-farm income & 362 & 1,102 & 352 & 1,053 & 1,136 & 2,906 & $*$ \\
\hline Conservation payments & 1 & 5 & 1 & 5 & 1 & 4 & $*$ \\
\hline \multicolumn{8}{|l|}{ Other } \\
\hline Crop diversity Gini $(0-1)$ & 0.91 & 0.03 & 0.91 & 0.03 & 0.91 & 0.04 & \\
\hline Debt-to-asset ratio & 0.18 & 1.87 & 0.18 & 1.88 & 0.22 & 1.34 & \\
\hline Operator age & 52 & 12.66 & 52 & 13 & 49 & 12.91 & $* *$ \\
\hline Acres operated & 995 & 1,306 & 996 & 1,299 & 972 & 1,749 & \\
\hline Crop acres & 839 & 1,059 & 840 & 1,053 & 785 & 1,438 & \\
\hline Rental ratio & 0.68 & 0.36 & 0.68 & 0.36 & 0.66 & 0.36 & \\
\hline$N$ & \multicolumn{2}{|c|}{37,535} & \multicolumn{2}{|c|}{36,484} & \multicolumn{2}{|c|}{1,051} & \\
\hline \multicolumn{8}{|c|}{$\begin{array}{l}\text { Note: Significance tests are conducted using Stata svy postestimation, which allows weighting (see www. } \\
\text { stata.com/manuals } 13 / \text { rttest.pdf for details). All variables are from the USDA ARMS database, years } 2003-2011 \text {. } \\
\text { Summary statistics are weighted means and standard deviations using ARMS sampling weights and calculated } \\
\text { after excluding farms without cash rental rate information, those with less than } \$ 5,000 \text { in total value of produc- } \\
\text { tion as well as farms that were predominantly livestock, woody tree, or nursery production, or located in a crop } \\
\text { reporting district without observed organic farms. Land value is the estimated value for rented-not owned-land. } \\
\text { Rental ratio is the ratio of rented to total operated acres. In ARMS, premiums are included in the fixed cost } \\
\text { variable. Production revenue is revenue from commodity sales only; other sources of income are considered } \\
\text { separately. ROVC is the return over variable cost equal to production revenue minus variable cost. All per acre } \\
\text { variables are winsorized at the top } 1 \% \text {. ROVC per acre was winsorized at the bottom and top } 1 \% \text {. We inflate all } \\
\text { dollar-denominated variables to } 2011 \text { (the last year of data we use) using the GDP deflator. } \\
\quad * p<0.1 ; * * p<0.05 ; * * * p<0.01 \text { (from } t \text {-tests of organic versus conventional means). }\end{array}$} \\
\hline
\end{tabular}

cant differences in means for between organic and conventional farms.

We calculate per-acre land prices, revenues, and variable costs by dividing farmlevel quantities by the farm's cropland acres. We calculate farmland rental rates as total cash rent paid divided by the number of cash rented acres. For other variables we divide by the total number of cropland acres. We must use per-acre quantities because we cannot assign any observed farm-level quantity for variables like revenues, costs, and subsidy receipts to operations on rented land.
Revenues include only sales of commodities; crop insurance indemnities, subsidy receipts, and off-farm income are reported separately. Receipts of environmental or conservation subsidies, namely payments from the CSP and the Conservation Reserve Program (CRP) are not included with other subsidy payments and are reported separately. We report profit in terms of returns over variable costs (ROVC). This is akin to what accountants define as the contribution margin, although our revenue and variable cost measures are not enterprise-specific; they are 
calculated for all of the farm's outputs and divided by all of the farm's crop acres. The variable cost measure is calculated as the sum of seed, fertilizer, chemical, fuel, labor, custom work, maintenance, utilities, and other variable costs. The only major variable costs excluded are crop insurance premiums, which are confounded with other insurance expenses in the ARMS. At the mean, conventional and organic farms look remarkably different for most whole-farm and per-acre revenue and cost measures. Organic farms, on average, have higher revenues and costs. Table 1 shows that organic farms on average earned more revenue and paid roughly double in variable costs. Average organic per-farm ROVC was greater but not statistically significantly so $(\$ 184,000$ versus $\$ 165,000)$. In per-acre terms, organic farms in our sample see much higher per acre variable costs than conventional farms $(\$ 2,001$ versus $\$ 387)$ and higher per acre revenues $(\$ 2,964$ versus $\$ 626)$. These organic farms have higher variable costs in every category, but the greatest difference is in hired labor, where organic farms spend nearly 10 times (\$758 versus \$76) what conventional farms pay per acre. Some of this difference may be caused by a greater proportion of organic farms having labor-intensive specialty crop production than conventional farms. (Summary statistics for variable costs are not disaggregated by category in Table 1 but are available in the Appendix.)

Conventional farms received slightly more in government subsidy payments than organic farms on average (\$19 versus \$16 per acre), consistent with the idea that existing government subsidy programs are targeted toward conventional row-crop commodity production. (However, this difference is not statistically significant.) Differences in participation in government programs targeted to conservation and environmental objectives, namely, CRP and CSP, are not economically significant, although they are marginally statistically different. There is little difference in debt-to-asset ratio, average operator age, or number of crops grown. There is also very little difference in the ratio of rented acres to total operated acres.

Land value characteristics differ between the two groups. The average cropland rental rate for organic farms (\$253) is substantially higher than that of conventional farms (\$110). The estimated value of that land is also significantly, substantially greater for organic than for conventional farms. The average total cropland and total acres operated for farms with organic acreage in our sample are slightly less than conventional, but neither difference is statistically significant.

Generally, for all farm-level variables in our data, there is large within-group variation. For nearly all variables measured in dollarper-acre terms, the median is less than the mean, indicating a right-skewed distribution. In these summary statistics, mean values do not represent a typical farm. They especially do not represent a typical row-crop farm in the U.S. Midwest, even though this is the most common farm type and location in our sample. Instead, our summary statistics highlight the heterogeneity of U.S. farms.

\section{Additional Data Sources}

We augment farm-level data from the ARMS with county-level characteristics from other sources. These data include time-invariant information about the counties in which farms are located that would otherwise be captured in farm fixed effects. These characteristics are matched to farm-level observations because we know the county in which each farm is located. From the 2002 Census of Agriculture, we include measures of the number of organic farms in the county and the proportion of irrigated cropland. The number of organic farms provides information on potential competition for organic land. The proportion of irrigated land may help explain differences in rental rates across counties. Both measures are predetermined with respect to observable farm-level rental rates and organic status. We also have data on county-level household income from the 1999 census and the degree to which the county is urbanized from the 2003 Rural-Urban Continuum codes. These codes classify counties on a 1-9 ordinal scale based on metropolitan population, degree of urbanization, and proximity to other urban areas. These variables may be informative with respect to the demand for organic crops and ur- 
Table 2

Summary Statistics for County-Level Variables Applied to Farm-Level Observations by Organic Status

\begin{tabular}{|c|c|c|c|c|c|c|c|}
\hline & \multicolumn{2}{|c|}{ Total Sample } & \multicolumn{2}{|c|}{ Conventional } & \multicolumn{2}{|c|}{ Organic } & \\
\hline & Mean & St. Dev. & Mean & St. Dev. & Mean & St. Dev. & \\
\hline Organic farms in county & 4.52 & 9.38 & 4.39 & 9.03 & 14.55 & 21.34 & $* * *$ \\
\hline Proportion irrigated & 0.14 & 0.28 & 0.14 & 0.27 & 0.34 & 0.40 & $* * *$ \\
\hline Soil productivity index $(0-1)$ & 0.55 & 0.21 & 0.55 & 0.21 & 0.42 & 0.22 & $* * *$ \\
\hline Household income $(\$ / 1,000)$ & 37.53 & 7.33 & 37.50 & 7.30 & 39.51 & 9.22 & $* *$ \\
\hline Urban-rural index (1-9) & 5.06 & 2.49 & 5.07 & 2.48 & 4.27 & 2.49 & $* * *$ \\
\hline$N$ & \multicolumn{2}{|c|}{37,535} & \multicolumn{2}{|c|}{36,484} & \multicolumn{2}{|c|}{1,051} & \\
\hline
\end{tabular}

Note: Significance tests are conducted using Stata svy postestimation, which allows weighting (see www.stata. com/manuals13/rttest.pdf for details). All variables are from the USDA NASS Census of Agriculture, except the county soil productivity index, which is from the USDA NRCS Soil Survey Geographic Database (SSURGO). The urban-rural index takes on values of one through nine, where nine is the most rural. The number of organic farms per county was estimated in 2002 and household income in 1999 using census data.

$* p<0.1 ; * * p<0.05$; *** $p<0.01$ (from $t$-tests of organic versus conventional means).

ban pressures on farmland values and rental rates.

The ARMS does not provide measures of (time-invariant) soil quality at the farm level. To incorporate differences in soil quality for ARMS-surveyed farms, we use the county-level Natural Resource Conservation Service Soil Survey Geographic (SSURGO) Database (Natural Resources Conservation Service 2017). SSURGO contains data on soil characteristics, including summary measures of soil quality known as the National Commodity Crop Productivity Indexes (NCCPI). These indexes measure county acre-weighted averages of overall soil productivity for various crops-corn and soybeans, small grains, and cotton, ranging from 0.01 (low productivity) to 0.99 (high productivity). We assign each farm the highest of these three county-level indexes.

Table 2 summarizes the county-level variables matched to farm-level observations in our dataset. These are means and standard deviations for the farms, not counties. Organic farms in our sample are in counties with many more organic farms. The average organic farm in our sample was in a county with approximately 14.5 organic farms. The average conventional farm had only 4.4 organic farms in its county. Organic farms in our sample are located in counties with lower average prevalence of irrigation (34\% versus 14\% of cropland acres irrigated) and lower soil quality ( 0.42 versus 0.55 soil productivity index).
County average household income and rural status were modestly different between the two groups. Organic farms tended to be in wealthier, more urban counties. These differences are all statistically significant, at least at the 5\% level, despite the relatively small number of organic farms and the large variance in each group.

Using data on the number of U.S. organic crop farms in the 2002 census, we can also compare the organic farms in our dataset to the population of U.S. organic and conventional farms. Organic farms, by construction, are more prevalent in our sample than in the general population. In the 2002 census, approximately $0.4 \%$ of all crop farms were organic, compared with $2.8 \%$ in our data from the proceeding eight years. In 2002, the average county had 2.4 organic farms and the median county had none. In the 1,467 counties with at least 1 organic farm in 2002, the average county had 4.9 organic farms, similar to the average number of organic farms in the counties of the farms in our data. For the population of U.S. organic farms in 2002, the expected number of organic farms in the county of a randomly selected organic farm is 19.3, though this figure is skewed by a few counties with many organic farms. Recall that the average organic farm in our sample was in a county with 14.5 organic farms. Therefore, although the organic farms in our ARMS-derived sample are located in counties with far more organic farms than would be found in 
the average U.S. county, they are in fact less likely to be located in hot spots of organic production (Marasteanu and Jaenicke 2016) than a randomly selected organic farm. This condition fosters a balance between being representative of the population of U.S. organic crop farms and allowing for suitable comparison between organic and conventional farms in our sample.

\section{Econometric Model}

Our goal is to properly specify an econometric model that accurately estimates the marginal willingness to rent an acre of organic farmland. We consider the relationship between organic certification and farmland rental rates using comparisons of organic and conventional farms. We observe $r_{i j t}$, the farmland cash rental rate paid by farm $i$ in CRD $j$ at year $t$. We also observe the proportion of the farm's cropland acres used to harvest certified organic crops, $\mathrm{Org}_{i j t}$. Ideally, we could treat organic status as randomly assigned and estimate the average treatment effect, $\gamma$,

$r_{i j t}=\beta_{0}+\gamma O \operatorname{Org}_{i j t}+\varepsilon_{i j t}$.

The average treatment effect in this simple model is the difference between mean $r_{i j t}$ for organic and conventional farms, assuming all farms are wholly organic or wholly conventional. Because we know that there are systemic differences in location, crop choice, scale, and other factors between organic and conventional farms, this simple model suffers from omitted variable bias. Many of these omitted variables are time-invariant, so farmlevel fixed effects and differencing are attractive methods for identifying $\gamma$. However, farm-level fixed effects are difficult if not impossible to apply to the farm-level estimation of equation [2]. The problem stems from the small number of organic farms in the United States and the infrequency with which farms transition from conventional to organic. If we include farm-level fixed effects, all identification of the effect of certification would be driven by the temporal variation in rental rates on farms that transition some portion of their acreage. In a representative sample of U.S. farms, this occurs extremely infrequently. The presence of a small number of treatment farms also creates a power problem. For a fixed farm-level sample size, the ability to detect any treatment effect is a direct function of the size of the treatment group. One solution to a lack of power is to increase sample size. We use the largest known survey of farm financial information, the ARMS, which does not intentionally sample the same farms in multiple years so that farm-fixed effects are infeasible.

Because within-farm variation in organic status is unavailable, we construct a control group from observed conventional farms. We first control for time-invariant unobservables and temporal variation at some level of spatial aggregation above the farm-level. We add spatial fixed effects to the model in equation [2] and include time fixed effects to flexibly address changes in the value of all agricultural land over time,

$r_{i j t}=\gamma \operatorname{Org}_{i j t}+f_{j}+d_{t}+\varepsilon_{i j t}$,

so that represents a comparison of organic and conventional farms in the same area after adjusting for common changes in rental rates across time. Making these spatial areas as small as possible approaches the ideal of farm-level fixed effects, but there must be both organic and conventional farms in each region to make these comparisons feasible. We include location fixed effects at the CRD level. ${ }^{5}$ CRDs are larger than counties but smaller than states. Including these spatial fixed effects is important for addressing omitted variables bias in hedonic property value estimation (Kuminoff, Parmeter, and Pope 2010) because these fixed effects explain much of the observed variation in land prices not attributable to the treatment.

\footnotetext{
${ }^{5}$ In repeated cross-sections such as the ARMS, pseudo-panel methods (Deaton 1985) are an alternative to spatial fixed effects whereby farm-level data are aggregated to a higher level of repeated observation (e.g., county, CRD, state). The treatment measure is the average of the treatment variable for all farms at the given time-CRD. Although some previous studies using the ARMS estimate pseudo-panel regressions, the small number of treated farms in our sample creates problems of precision. Since there are very few organic farms in any given CRD, there is large variance in the CRD-level treatment.
} 
In addition to spatial and temporal fixed effects, we condition our comparisons of organic and conventional farms on a vector of other observable variables, $\mathbf{X}_{i j t}$, related to land rental rates, so that we estimate the following regression equation:

$$
r_{i j t}=\gamma \operatorname{Org}_{i j t}+\mathbf{X}_{i j t} \beta+f_{j}+d_{t}+\varepsilon_{i j t} .
$$

To allow for interpretation of the estimated coefficients as elasticities and semi-elasticities, we transform all continuous dollar-denominated variables using an inverse hyperbolic sine (IHS) transform, similar to taking the $\log$ of these variables but allowing for zero-valued observations (Burbidge, Magee, and Robb 1988; Bellemare and Wichman 2020). Using equation [4] to identify $\gamma$ is a selection-on-observables design reliant on the variables in $\mathbf{X}_{i j t}$ to ensure the conditional independence of organic status with respect to land rental rates. Because our research design is vulnerable to misspecification bias due to omitted variables, we attempt to control for as many potential exogenous confounders as possible and consider potential unobservables that may bias our results through correlation with the unexplained portion of farm-level rental rates, $\varepsilon_{i j t}$.

Variables in the vector of controls $\mathbf{X}_{i j t}$ should be related to land rental rates and correlated with a farm's organic status to bring us closer to conditional independence. Some of these variables are time-invariant characteristics of the farm or county that would have been captured by farm or county fixed effects had we been able to include them. Specifically at the county level, we control for proximity to urban centers using the Urban Rural Index, average household income, soil productivity, proportion of cropland irrigated, and the number of organic farms. Some of these controls are related to the demand for organic farmland and competitiveness of the local farmland market (urban-rural indicators, income, number of organic farms in 2002). Others are related to agronomic differences across counties that might be correlated with the presence of organic farms and rental rates.

We also include in $\mathbf{X}_{i j t}$ some observable farm-level characteristics. Our objective is to adjust the estimated difference between organic and conventional rental rates for farm-specific differences in other factors related to willingness to pay for land as a farm input. Again, some of these factors are time-invariant. We include them as covariates given our repeated cross-section. Specifically, we observed whether the farm primarily produces (derives the majority of its revenue from) row crops, cotton, tobacco, fruits and nuts, or vegetables, the level of cropping diversification on the farm measured by the Gini coefficient of crop-specific acreage, ${ }^{6}$ the farm's receipts of decoupled subsidy payments (specifically payments from the Direct and Counter-Cyclical Payments programs available during this period), receipts of conservation-related subsidy payments (specifically the CSP and CRP programs), fixed production costs, farm debtto-asset ratio, household off-farm income, and operator age.

Policy variables that affect farm-level production decisions such as organic conversion provide an attractive opportunity for econometric identification. If there is some government program that exogenously spurred organic conversion, we could exploit that variation by using policy uptake as an instrument for $\operatorname{Org}_{i j t}$ to identify $\gamma$. For example, Kuminoff and Wossink (2010) motivate their estimates of the option value of organic conversion using the introduction of the CSP as an exogenous shock to farmers expectations of organic profitability. In our case, one could argue that the CSP changed farmer expectations about the relative profitability of organic farming, and since the program was rolled out randomly across watersheds, this variation is plausibly exogenous to other factors affecting rental rates. However, real-world experience with this program suggests that CSP participation or eligibility are unlikely to be useful instrumental variables. Few farms availed themselves of CSP, and CSP payments were

\footnotetext{
${ }^{6}$ We summarize crop diversity at the farm level by calculating a Gini coefficient using the farm's harvested acres by crop. ARMS records harvested acres for 20 unique crops or crop categories. The Gini coefficient encapsulates the number of crops grown and the share of acres allocated to each crop. A farm that grows only one of these crops would have a crop acreage Gini coefficient of 1 . A farm that equally allocates acres across all of these categories would have a Gini coefficient of 0 .
} 
very small (as Kuminoff and Wossink [2010] note). In our data, participation differs little between organic and conventional farms. ${ }^{7}$

\section{Identification in the Presence of Variables Determined after Treatment}

Using a selection-on-observables design that adjusts for the (plausibly exogenous) confounders given above requires us to consider what variables might still be omitted from equation [4]. Because farmland rental rates are driven by expected farm profits, it would be tempting to control for farm-level revenues and costs that we observe in the ARMS. Indeed, many other farmland studies control for observed profit, particularly in the literature estimating the effect of subsidy payments on farmland rental rates and land values. In our case these variables are partly determined by the treatment variable, $\mathrm{Org}_{i j t}$. Because organic certification is expected to affect per-acre profit and expected profit determines willingness to pay for farmland, these variables fit the definition of "bad controls" in that they "are themselves outcome variables in the notional experiment at hand" (Angrist and Pischke 2009, 65). That is, revenues and costs incurred in the year in which we observe a given farm in our data are determined after treatment.

We are reticent to simply throw away the information contained in observed revenues and costs because observed profits are closely related to the unobservable expected profit that determines what farmers are willing to pay to rent land. While some of the covariates in $\mathbf{X}_{i j t}$ are also related to farmers expected profit, others are not. Many studies of farmlevel rental rates motivate the use of differences-in-differences or farm-level fixed effects with an appeal to unobservable time-invariant "management ability" that might explain why some farms have different expected profits using the same mix of observable inputs.

\footnotetext{
${ }^{7}$ ARMS does not contain complete information on the CSP participation for all farms. Between 2005 and 2011, approximately one-quarter of ARMS phase 3 respondents in our sample were asked to report the CSP payment receipts. For this subsample, only $4.5 \%$ report receiving a CSP payment, and there are not significant differences in CSP participation or payments between organic and conventional farms.
}

(Therefore, productivity differences at the farm level might explain why some farms are willing to pay more or less for land.) We cannot explicitly control for management ability, but observed accounting profits in the survey year may be a useful, if noisy, measure of unobservable expected profits, which are determined in part by management ability.

In addition, observing profitability may inform us about the mechanism by which organic certification affects farmers' willingness to pay for farmland. Some existing research (Trujillo-Barrera, Pennings, and Hofenk 2016) suggests that the motive of higher expected profit is the primary reason farmers adopt production practices related to environmental sustainability. Other research suggests that greater profitability is not the primary perceived benefit of conversion to organic production (Cranfield, Henson, and Holliday 2010). If the profit motive drives organic adoption for U.S. crop producers, higher expected per-acre profits should motivate higher bids for land capable of producing certified organic crops. Observed profits are a potentially important proxy for expected profits along a causal path between organic status and land rental rates. As measures of profit, we observe revenue from cash and contract sales and variable costs, including seed, chemical, fertilizer, and labor. These revenue and cost items may vary significantly in peracre terms between organic and conventional farms. The open question is whether it is profit (as measured by the difference between these revenues and costs) that causes organic farms to pay more for land or some other mechanism.

If profit is a "bad control" in the terminology of Angrist and Pischke (2009) but important for our understanding of the relationship between organic status and land rental rates, how should we use this information? We partition $\mathbf{X}_{i j t}$ into a vector of pretreatment-determined variables $\mathbf{X}^{\text {pre }}$ and posttreatment-determined variables $\mathbf{X}^{\text {post }}$ that include profit observed at $t$.

Simply including posttreatment variables including observed profit as controls as in

$$
\begin{aligned}
r_{i j t}= & \gamma \operatorname{Org}_{i j t}+\mathbf{X}^{\text {pre }} \boldsymbol{\beta}^{\text {pre }}+\mathbf{X}^{\text {post }} \boldsymbol{\beta}^{\text {post }} \\
& +f_{j}+d_{t}+\varepsilon_{i j t}
\end{aligned}
$$


risks biasing our estimates. To see why, consider the interpretation of the coefficient $\gamma$ in equation [5]. Here $\gamma$ estimates the effect of organic certification holding organic and conventional per-acre profitability at similar levels. This is explicitly not the comparison we want to make, since we expect organic certification may affect the relationship between profitability and willingness to pay for farmland. For example, we do not want to compare farmland rental rates for farms with the same level of expected profit, but to compare farms with the same level of expected profit under a given production system (conventional or organic).

\section{Controlled Direct Effects}

The nascent literature on mediated effects (e.g., Pearl 2001; Imai et al. 2011) provides an alternative to undesirable specifications that simply include or exclude observed revenues and costs. We estimate the controlled direct effect (CDE) developed by Acharya, Blackwell, and Sen (2016) and applied in economics as in Moya (2018) and Assuncao, Braganca, and Hemsley (2019). This estimator represents "the causal effect of a treatment when a mediator variable is fixed at a particular level" (Acharya, Blackwell, and Sen 2016, 513), specifically the level observed by researcher. In our case, we consider expected profit as the mediator variable, $M$, and hold it fixed at the level observed after the farm makes the decision to certify production as organic. The CDE measures the relationship between organic certification and willingness to pay for farmland apart from the profit mechanism.

Figure 2 describes these two causal paths between organic status and rental rates. One is the effect mediated by expected profits (labeled E(Profit) in Figure 2); organic status changes the farmer's profit expectations, which cause them to increase their willingness to pay for land. The second (shown as an arcing path from Organic to Rental Rate in Figure 2) represents the CDE or the direct effect of organic status on rental rates absent a change in expected profit. Acharya, Blackwell, and Sen (2016) show the CDE is identified under the assumption of "sequential unconfoundedness" which is essentially two
Figure 2

Directed Acyclic Graph Showing Causal Paths between Organic Status and Rental Rates and Violations of the Sequential Unconfoundedness Assumption

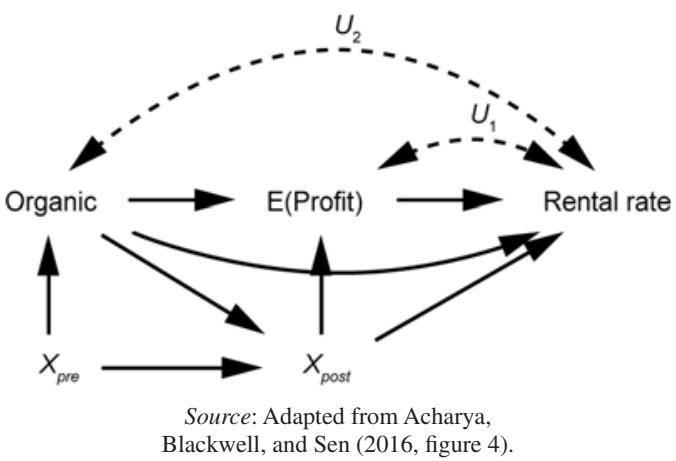

no-omitted-variables assumptions common in selection-on-observables designs. Sequential unconfoundedness assumes no omitted variables confound the estimation of the treatment effect, conditional on all pretreatment variables, and that no omitted variables confound the estimate of the mediator effect on the outcome, conditional on the treatment, pretreatment confounders, and intermediate confounders. Violations of these assumptions are represented by the dashed lines labelled $U_{1}$ and $U_{2}$ in Figure 2.

Although the identifying assumptions underlying the $\mathrm{CDE}$ are restrictive, Acharya, Blackwell, and Sen (2016) show that it is possible to examine the sensitivity of the estimated effects to some violations of the sequential unconfoundedness assumption. First, we consider the unobserved variables $U_{1}$ and $U_{2}$ that might exist in our application. Regarding $U_{1}$, we observe realized profit so $U_{1}$ is a measurement error bias due to differences between expected and realized profits. Assuming these errors are mean 0 , the estimated effect of expected profit on rental rates is biased toward 0 . Because the magnitude of the bias depends on the variance of the measurement error, the bias is almost certainly smaller when considering profit expectations for the coming year and rental rates as the outcome. Measurement error for expected profit in all future periods will be larger, highlighting the benefit of using rental rates rather than land values as our outcome of interest. Acharya, Blackwell, and 
Sen (2016) show that bias due to omitted posttreatment confounders is eliminated when the correlation between $U_{1}$ and $U_{2}$ is 0 or when the effect of the treatment on the mediator is 0 . For this reason, we later explore the relationship between organic status and observed profitability in our sample.

$U_{2}$ represents remaining omitted variables that explain differences in rental rates between organic and conventional farms in the same CRD. Perhaps the most important are the farm-specific components of variables that we only observe at the county level, such as soil productivity. Identification of the organic effect (but not the effect of the county-level variables themselves) requires that farm-specific deviations from the area average are uncorrelated with the farm's organic status. Signing the bias in this case is difficult because we have no information on the correlation between farm-specific soil productivity and organic status and because organic conversion may cause changes in soil quality. We leave the exploration of this phenomenon for future work. Of course, there may be remaining farm-level omitted variables that lead to bias in the estimated organic effects. The ARMS has the advantage of containing more farm-level information than other available data, but there may still be omitted confounders beyond the farm-specific deviations from county-level measures.

The time lag associated with organic conversion may alleviate some endogeneity concerns in the relation between organic status and farmland rental rates. Recall that organic certification requires a three-year transition period during which production cannot be sold as certified organic. Farms in our data classified as organic at $t$ must have decided to certify at least three years prior, and farmland rental rates observed at $t$ cannot directly affect contemporaneous organic status. The existence of a mandatory transition period may prevent reverse causality from farmland prices to organic status and eliminate the $U_{1}$ path in Figure 2. However, dynamics in either farmland prices or unobservables related to both farmland prices and organic conversion at $t$ may still confound identification of the organic treatment effect (Bellemare, Masaki, and Pepinsky 2017). We know various rigid- ities in farmland markets lead to dynamics in farmland rental rates at the farm-level (Hendricks, Janzen, and Dhuyvetter 2012), but we cannot observe these dynamics for farms in our data. Still, the duration of the organic transition period may be long enough that dependence between variables that influenced the past conversion decision and current farmland rental rates is negligible.

We apply the Acharya, Blackwell, and Sen (2016) method as follows, estimating the controlled direct effect using a two-stage regression procedure. The first stage estimates an unrestricted regression equation that includes posttreatment controls as in equation [5]. Production revenue and variable costs are posttreatment controls. ${ }^{8}$ Using the estimated coefficients for the mediator variables from the first stage, $\hat{\beta}_{M}$, we "demediate" the dependent variable by subtracting the observed effect of the mediator variables on the outcome.

Specifically, we calculate $\hat{r}_{i j t}=r_{i j t}-\hat{\beta}_{M} M_{i j t}$, where $M_{i j t}$ is a vector of mediator variables that includes revenue and variable costs observed for farm $i$ in year $t$. To estimate the effect of organic status apart from the effect that operates through the profit mechanism, we estimate a second-stage regression of the demediated dependent variable, $\hat{r}_{i j t}$, on organic status and the remaining pretreatment controls.

The coefficient estimate on organic status from the second stage is the controlled direct effect of organic conversion on farmland rental rates. If organic status has a statistically significant relationship with farmland rental rates in the second-stage regression, we conclude that the effect of organic certification on observed willingness to pay for farmland must operate through mechanisms other than profit. If we cannot reject the null hypothesis of no effect, we conclude that organic certification leads to higher per-period land prices at least partly through the proposed profit mechanism. Because the standard errors from the second-stage regression ignore variability from the first-stage and demediation steps, statis-

\footnotetext{
${ }^{8}$ In alternate specifications for the CDE estimation procedure, we considered other variables included in $\mathrm{X}_{i j t}$ as posttreatment controls, specifically debt-to-asset ratio and crop diversification. Doing so did not meaningfully change our result; it increased the estimated CDE by just 0.0001 .
} 
Table 3

Farmland Rental Rate Regression Results

\begin{tabular}{|c|c|c|c|c|c|}
\hline Equation & (2) & (3) & (4a) & (4b) & (5) \\
\hline Organic status & $\begin{array}{l}0.723^{* * *} \\
(0.157)\end{array}$ & $\begin{array}{l}0.354^{* * * *} \\
(0.115)\end{array}$ & $\begin{array}{l}0.366^{* * *} \\
(0.111)\end{array}$ & $\begin{array}{l}0.346^{* * *} \\
(0.102)\end{array}$ & $\begin{array}{l}0.273^{* * *} \\
(0.079)\end{array}$ \\
\hline Soil productivity & & & $\begin{array}{l}1.072 * * * \\
(0.097)\end{array}$ & $\begin{array}{l}1.051^{* * * *} \\
(0.094)\end{array}$ & $\begin{array}{l}0.821 \text { *** } \\
(0.087)\end{array}$ \\
\hline Organic farms in county & & & $\begin{array}{c}0.001 \\
(0.001)\end{array}$ & $\begin{array}{c}0.001 \\
(0.001)\end{array}$ & $\begin{array}{c}0.001 \\
(0.001)\end{array}$ \\
\hline County percent irrigated & & & $\begin{array}{l}0.675^{* * * *} \\
(0.064)\end{array}$ & $\begin{array}{l}0.625 * * * \\
(0.064)\end{array}$ & $\begin{array}{l}0.363 * * * \\
(0.057)\end{array}$ \\
\hline County household income & & & $\begin{array}{l}0.257 \text { *** } \\
(0.068)\end{array}$ & $\begin{array}{l}0.248 * * * \\
(0.068)\end{array}$ & $\begin{array}{l}0.181 \text { *** } \\
(0.066)\end{array}$ \\
\hline Crop diversity Gini & & & & $\begin{array}{l}1.323 * * * \\
(0.227)\end{array}$ & $\begin{array}{l}1.192 * * \\
(0.208)\end{array}$ \\
\hline Fixed costs & & & & $\begin{array}{l}0.053 * * * \\
(0.009)\end{array}$ & $\begin{array}{c}0.004 \\
(0.009)\end{array}$ \\
\hline Subsidy receipts & & & & $\begin{array}{l}0.035^{* * * *} \\
(0.005)\end{array}$ & $\begin{array}{l}0.022^{* * *} \\
(0.005)\end{array}$ \\
\hline Off-farm income & & & & $\begin{array}{l}0.026 * * * \\
(0.003)\end{array}$ & $\begin{array}{l}0.024 * * \\
(0.003)\end{array}$ \\
\hline Debt-to-asset ratio & & & & $\begin{array}{l}0.005^{* * *} \\
(0.001)\end{array}$ & $\begin{array}{l}0.004 * * \\
(0.001)\end{array}$ \\
\hline Operator age & & & & $\begin{array}{l}0.004 * * * \\
(0.001)\end{array}$ & $\begin{array}{l}0.003 * * * \\
(0.001)\end{array}$ \\
\hline Conservation payments & & & & $\begin{array}{l}0.046^{* * * *} \\
(0.006)\end{array}$ & $\begin{array}{l}0.018 \text { *** } \\
(0.006)\end{array}$ \\
\hline Production revenue & & & & & $\begin{array}{l}0.295^{* * *} \\
(0.016)\end{array}$ \\
\hline Variable costs & & & & & $\begin{array}{l}0.118^{* * *} \\
(0.017)\end{array}$ \\
\hline Crop insurance indemnities & & & & & $\begin{array}{l}0.014 * * \\
(0.003)\end{array}$ \\
\hline$R$-squared & 0.004 & 0.485 & 0.497 & 0.515 & 0.560 \\
\hline
\end{tabular}

Note: The dependent variable for all regressions is the cash rental rate. The sample size for all regressions is 37,535. Tables 1 and 2 provide variable descriptions. Heteroskedasticity-robust standard errors are in parentheses. We suppress output for the following sets of fixed effects that are included in regressions corresponding to columns (3)-(5): year, farm type, crop reporting district, and urban proximity index. $* p<0.1 ; * * p<0.05 ; * * * p<0.01$.

tical significance of the estimated controlled direct effect is determined using standard errors generated by a nonparametric bootstrap procedure.

\section{Results}

We estimate the single-stage, single-equation regressions following equations [2]-[5] using ordinary least squares. Although we emphasize estimation of $\gamma$, the coefficient associated with organic status, we consider differences in explanatory power across these regressions as a way to understand the considerable cross- farm heterogeneity found in our data. We know that differences in farmland rental rates are driven by local factors obscured in national summary statistics, so preliminary regressions help us understand the source of variation in farmland rental rates. Table 3 contains these regression results. Column (2) shows results of regressing the farmland rental rate on only the organic treatment variable; this estimate suggests there is a significant $72 \%$ difference in rental rates between conventional and organic cropland, but the regression holds little overall explanatory power.

Table 3, column (3) shows the results of regressing rental rate on the organic treat- 
ment variable and a set of fixed effects. Recall that fixed effects include year, farm type, crop reporting district, and urban proximity index. These fixed effects, particularly spatial fixed effects at the crop reporting district level, do much of the heavy lifting in terms of the explanatory power of the regression; the $R^{2}$ increases from close to 0 to nearly 0.5 . Column (4a) includes county-level variables summarized in Table 2-the number of organic farms, the proportion of irrigated cropland, and the median household income. Both the proportion of land in the county that is irrigated and the median household income are positive and significant predictors of observed rental rates. The number of organic farms, which we include as a measure of competition in the market for organic land, is not significant in explaining rental rates. Column (4b) includes all pretreatment variables (i.e., all variables with values we believe are determined independently from farm-level organic status). Each additional variable is statistically significant, although the coefficients for debtto-asset ratio and operator age are sufficiently small to constrain their economic meaning to nearly nothing. The crop diversity Gini coefficient is a strong positive predictor of rental rate. Column (5) includes farm revenue- and cost-related variables determined after treatment that may be influenced by organic status. All posttreatment regressors-revenue, variable costs, crop insurance indemnities, and conservation subsidy payments-are statistically significant predictors of observed farmland rental rates.

Interpretation of the coefficient estimates in Table 3 depends on the set of conditioning variables and how each variable is expressed or transformed. Because we use an IHS transformation of the rental rate variable and many of the covariates, interpreting regression coefficients as elasticities or semi-elasticities may result in bias, as demonstrated by Bellemare and Wichman (2020). To address that potential bias, we adjust the coefficients of all variables from our preferred regression, as shown in column (5), using formulas described by Bellemare and Wichman (2020). Table 4 shows the results of those calculations. For conciseness, we report only elasticities calculated from regression results in

\section{Table 4}

Elasticities of Farmland Rental Rates with Respect to Changes in Observed Variables

\begin{tabular}{|c|c|}
\hline \multicolumn{2}{|l|}{ Semi-elasticities } \\
\hline Organic status & $\begin{array}{l}0.255^{* * * *} \\
(0.070)\end{array}$ \\
\hline Soil productivity & $\begin{array}{l}0.659 \text { *** } \\
(0.068)\end{array}$ \\
\hline Organic farms in county & $\begin{array}{c}0.000 \\
(0.001)\end{array}$ \\
\hline County percent irrigated & $\begin{array}{l}0.307 \text { *** } \\
(0.049)\end{array}$ \\
\hline Crop diversity Gini & $\begin{array}{l}0.856^{* * * *} \\
(0.148)\end{array}$ \\
\hline Debt-to-asset ratio & $\begin{array}{l}0.004 * * * \\
(0.001)\end{array}$ \\
\hline Operator age & $\begin{array}{l}0.000 * * * \\
(0.000)\end{array}$ \\
\hline Elasticities & \\
\hline County household income & $\begin{array}{l}0.195^{* * * *} \\
(0.060)\end{array}$ \\
\hline Fixed costs & $\begin{array}{c}0.008 \\
(0.475)\end{array}$ \\
\hline Off-farm income & $\begin{array}{l}0.019 \text { *** } \\
(0.002)\end{array}$ \\
\hline Conservation payments & $\begin{array}{l}0.003 \text { *** } \\
(0.001)\end{array}$ \\
\hline Production revenue & $\begin{array}{l}0.300 \text { *** } \\
(0.014)\end{array}$ \\
\hline Variable costs & $\begin{array}{l}0.129 \text { *** } \\
(0.014)\end{array}$ \\
\hline Crop insurance indemnities & $\begin{array}{l}0.004 * * * \\
(0.001)\end{array}$ \\
\hline
\end{tabular}

Note: Tables 1 and 2 provide variable descriptions. Standard errors are in parentheses. Year, farm type, crop reporting district, and urban proximity index fixed effects are included in the regressions used to compute the elasticities shown above, in addition to variables listed. $* p<0.1 ; * * p<0.05 ; * * * p<0.01$.

the tables that follow. Unadjusted regression results for all subsequent auxiliary regressions are available in the Appendix. Using this transformation and adjustment procedure allows us to interpret our results as semi-elasticities or elasticities. The majority of the regressors-including organic status-are measured either as indexes ranging from 0 to 1 or proportions with a similar range. Other variables reported in IHS of their dollar (or \$/ acre) values such as household income, production revenue, and variable costs are interpreted as elasticities.

After adjusting for observable covariates, farmland rental rates paid by organic farms remain higher than comparable conventional 
farms. ${ }^{9}$ We estimate an organic certification semi-elasticity of willingness-to-pay for farmland of 0.255 ; we expect a 10 percentage point increase in organic status to be associated with a $2.6 \%$ increase in the farmland rental rate. If we extrapolate this estimate linearly to the case where a farm with 0 organic acres were to fully certify all acres and production, we would expect that farm to pay $26 \%$ higher cash rent. In this case (and for the majority of variables in Table 4), the regression coefficient is relatively close to the calculated semi-elasticity; bias introduced by using the IHS to approximate the natural $\log$ is minimal.

Location accounts for much of the observed variation in rental rates across U.S. farms, but other factors help predict intraregional differences. A key predictor of rental rates is soil productivity; a 10 percentage point increase in the county-level soil productivity index is associated with a $6.6 \%$ increase in rental rate paid at the farm level. Other variables exhibiting (significant, positive) correlation with rental rates include irrigation, cropping diversity, county-level income, and farm-specific revenues and input expenditures. All farmlevel, income-related variables-production revenue, variable costs, subsidy receipts, crop insurance indemnities, and off-farm income-have statistically significant elasticities in Table 4.

Interpretation of estimated rental rate elasticities with respect to farm income variables is difficult; we include these variables because they may be correlated with the decision to certify as organic and profitability expectations that determine the market price of farmland. We do not expect higher input expenditures to make farmers more aggressive bidders in the land rental market. Instead, these variables are simply important conditioning information when estimated the effect of organic status on rental rates, helping predict intraregional differences in rental rates. Not surprisingly, the magnitude of the relation between pro-

\footnotetext{
${ }^{9}$ In the Appendix, we estimate similar regressions using farms' self-reported land values as the outcome of interest. We do not find similarly significant differences in land values for organic farms. As we note in Section 4, these land value regressions suffer potential bias because of additional omitted variables.
}

duction revenue and rental rates is large. We estimate farms with $10 \%$ higher production revenue pay $3 \%$ more in rent on average. The magnitude of the elasticity is greater for those variables that are directly tied to farmland production, rather than government payments that may not be related to production or offfarm income that may be entirely unrelated. ${ }^{10}$

\section{Estimating the Controlled Direct Effect}

Although estimates of $\gamma$ in columns (4b) or (5) suggest that organic farmers do pay higher cash rental rates, neither specification is ideal; (4b) omits important variables, and (5) adjusts for variables determined after treatment. To alleviate both concerns, we use the Acharya, Blackwell, and Sen (2016) method of estimating the $\mathrm{CDE}$ of organic status on rental rates. Equation [5] is the first-stage regression following this method. In a second stage, we estimate a version of (4b) that replaces the dependent variable, observed rental rates, with a "demediated" rental rate variable that removes the influence of posttreatment-determined revenues and variable costs. In this specification, the coefficient on organic status is 0.272 , which is nearly identical to the unconditional effect estimate of 0.273 in column (5) of Table 3. ${ }^{11}$ The bootstrapped standard error for this parameter estimate yields a $p$-value of 0.001. A small number (19) of the 500 attempted bootstrap replications fail because the model cannot estimate some of the large number of spatial fixed effects in column

\footnotetext{
${ }^{10}$ At the suggestion of an anonymous reviewer, we also ran our regressions with our observations reweighted by the proportion of land rented relative to total land operated. The results (available in the Appendix) are qualitatively similar; the coefficient on Organic is 0.39 rather than 0.27 , and other coefficients are similar to those we report here.

${ }^{11}$ In Section 4, we discuss the potential for downward bias in the CDE due to measurement error bias in the estimated relationship between profit and rental rates. To explore the effect of this bias, we perform an auxiliary CDE estimation procedure that assumes the coefficient on production revenue equals 0.6 , a value twice as large as estimated in Table 3. We find the CDE in this case is 0.226 compared to 0.273 in our main results. Therefore, even when we assume the bias is large, our result is qualitatively similar: organic rental rates are significantly greater than conventional and the effect does not operate through higher expected profits for organic farms.
} 
(5). The remaining estimates are sufficient to generate standard error estimates.

We interpret the roughly similar semi-elasticity estimate from the CDE estimation to suggest that significant differences in farmland rental rates paid by organic farms are not related to higher profits earned by those farms. Our initial finding that organic certification generates an approximately 26\% increase in willingness to pay for farmland persists after appropriately adjusting for observable factors, including profitability in the same year as observed rental rates. Because we can only select on observables, this main finding does not preclude bias in our estimated $\gamma$. For example, profit measures observed in the ARMS are at best noisy proxies for true management ability associated with higher willingness to pay for farmland. Future work using more suitable data, especially true panel data, should they exist, should address these concerns. To examine our main result further within the confines of available data, we check for heterogeneity in our main parameter estimate across subsamples and look directly at the observed correlation between organic status and contemporaneous farm profits.

\section{Exploring Parameter Heterogeneity}

We know that organic farms may be more prevalent among some production types, farm sizes, and regions. Organic farms are often typecast as relatively small-acre fruit and vegetable producers in California. If the economics of organic production differ along the dimensions above, willingness-to-pay for cropland may differ as well. We estimate separate regressions similar to those in column (5) of Table 3 for subsamples of our dataset. We do so for six production types: grains, oilseeds, and pulses; cotton; tobacco; vegetables; fruits and nuts; and hay and other crops. We also estimate separate regressions based on farm size (more or less than 640 acres), and ERS farm resource regions. ${ }^{12}$ The results of these regressions are included in the Appendix. One difficulty in estimating these regressions is maintaining adequate power in smaller

\footnotetext{
${ }^{12}$ See Economic Research Service (2017) for more detail on the ERS farm resource regions.
}

sample sizes. Our coefficient estimates remain fairly precise for subsamples with many farms, such as those growing grains and oilseeds and those in the U.S. Midwest.

Broadly speaking, our main results regarding the organic rental rate premium are consistent with estimates for grain and oilseed farms in the ERS Heartland region, which corresponds with the area colloquially known as the Corn Belt. The semi-elasticity of the change in rental rate with respect to organic status for grain and oilseed farms is 0.224 and for the Heartland region is 0.249 . We find significantly higher estimates for vegetable farms, other crop and hay farms, and for farms in the Northern Crescent around the Great Lakes and the U.S. Northeast. We find organic status to be associated with a higher rental rate premium for farms less than 640 acres, relative to larger farms. We do not find the organic semi-elasticity to be statistically significant for any other single farm type or group, at least partly because we lose precision due to smaller sample sizes. In general, we maintain our overall conclusion that organic farms pay higher rental rates than conventional farms do.

We also considered the potential for outlier or high-leverage observations to significantly affect our estimates. We know that the distributions of many variables in our data are rightskewed with many observations far above the median. To examine the implications of this skewness, we consider "high-value" farms with greater than $\$ 5,000$ per acre in revenue or variable costs. This subsample contains 1,090 high-value farms. These are mainly large fruit and vegetable farms in the ERS Fruitful Rim region (mainly in California, Washington, and Florida). There are proportionally more organic farms in this subsample. The semi-elasticity of the change in rental rate with respect to organic status for these high-value farms is 0.283 and is not statistically significant. The semi-elasticity for other farms is 0.222 ; both estimates are relatively similar to the those for grain and oilseed farms.

\section{Are Organic Farms More Profitable?}

To consider the origin of our null result regarding profit as mechanism for higher farmland rental rates, we directly compare revenues 
and variable costs on organic and conventional farms in our ARMS-derived sample of cash-renting U.S. farms. These estimates are descriptive, rather than causal, because organic status is likely a function of expected profitability correlated with the realized accounting profits we observe. Recall that the existing literature contains conflicting results for such profitability comparisons; Section 2 describes them in detail. Uematsu and Mishra (2012) is a salient comparison here because the authors use a single year of data from the same source (the ARMS) but rely on propensity score matching in this cross-section for identification. They find that organic farm profits are not significantly higher than conventional farms; greater organic revenues do not make up for higher production costs.

We estimate regressions similar to equation [4] with per-acre production revenue, variable cost, and return over variable cost as left-hand side variables, as in:

$\pi_{i j t}=\delta \operatorname{Org}_{i j t}+\mathbf{Y}_{i j t} \boldsymbol{\alpha}+f_{j}+d_{t}+\varepsilon_{i j t}$.

Here $\pi_{i j t}$ represents these left-hand-side variables. Org $g_{i j t}$ is, as before, the ratio of organic cropland to total cropland. $\mathbf{Y}_{i j t}$ is a vector of controls related to revenue, costs, or returns and likely correlated with organic status. Again we adjust for proximity to urban centers, average household income, soil productivity, proportion of cropland irrigated, and the number of organic farms, all at the county level. At the farm level, we control for crop diversity (measured by Gini coefficient), debtto-asset ratio, operator age, off-farm income, fixed costs, conservation payments, and farm type. We also employ CRD-level and year fixed effects, $f_{j}$ and $d_{t}$. We do not include revenue or variable cost variables.

As before, we transform continuous measures by IHS and report semi-elasticities for regressors measured either as indexes ranging from 0 to 1 or proportions that have a similar range and elasticities for other variables. We adjust the coefficients of all variables as described in Bellemare and Wichman (2020). Table 5 shows our semi-elasticity and elasticity estimates.

Organic status is not a statistically significant predictor of revenue, variable cost, or
ROVC. Organic farms in our data do not earn significantly higher average per-acre revenue or profit after adjusting for location, crop choice, soil productivity, and other factors. We find a positive relationship between both soil productivity and the predominance of irrigation in the county and all of the profit variables-revenue, variable costs, and ROVC. Fixed costs, off-farm income, and conservation payment receipts are associated with lower profits. The remainder of the variables generally do not have either statistically significant or economically significant correlations with per-acre ROVC.

When we run the same regressions for specific farm types, farm sizes, and regions, the correlation between organic status and ROVC either remains ambiguous or is negative for the majority of those groups. (These regression results are available in the Appendix.) Grain and oilseed, tobacco, and fruit and nut farms exhibit a negative, statistically significant relationship between organic status and ROVC. For other farm types-those that predominantly grow cotton, vegetables, and other crops - the organic coefficient in the ROVC regression is not statistically significant. We do not find significant differences in organic and conventional profits on small or large farms. Finally, there is a negative and statistically insignificant relationship between organic status and ROVC for the Heartland and Fruitful Rim regions that is important in our main results. The general negative association between per-acre profit and organic status holds over several alternative measures of net income (not shown here). These include profit per acre in which crop insurance indemnities are included as revenue, and profit per acre in which land rental charges or fixed costs are included as costs. In these specifications, the estimated $\delta$ coefficient associated with $\mathrm{Org}_{i j t}$ is negative and significant.

We can compare our results to Uematsu and Mishra (2012) with some caveats. They find greater total production revenue on organic farms but not greater profit. While our per-acre point estimates in the first row of Table 5 are consistent with their finding that higher costs outweigh greater revenue on organic farms, these results are not statistically significant. Uematsu and Mishra (2012) sug- 
Table 5

Elasticities of Profit Measures with Respect to Changes in Observed Variables

\begin{tabular}{|c|c|c|c|}
\hline Dependent Variable & Revenue & Variable Cost & ROVC \\
\hline \multicolumn{4}{|l|}{ Semielasticities } \\
\hline Organic status & $\begin{array}{c}0.154 \\
(0.117)\end{array}$ & $\begin{array}{c}0.229 \\
(0.113)\end{array}$ & $\begin{array}{c}-0.795 \\
(0.791)\end{array}$ \\
\hline Soil productivity & $\begin{array}{l}0.579 * * * \\
(0.074)\end{array}$ & $\begin{array}{l}0.318^{* * * *} \\
(0.082)\end{array}$ & $\begin{array}{l}1.226^{* * * *} \\
(0.550)\end{array}$ \\
\hline Organic farms in county & $\begin{array}{c}0.000 \\
(0.001)\end{array}$ & $\begin{array}{c}0.001 \\
(0.001)\end{array}$ & $\begin{array}{c}-0.006^{*} \\
(0.005)\end{array}$ \\
\hline County percent irrigated & $\begin{array}{l}0.647 * * * \\
(0.058)\end{array}$ & $\begin{array}{l}0.525^{* * *} * \\
(0.058)\end{array}$ & $\begin{array}{l}0.772 * * * \\
(0.354)\end{array}$ \\
\hline Crop diversity Gini & $\begin{array}{l}0.457^{* * *} \\
(0.165)\end{array}$ & $\begin{array}{c}-0.257 \\
(0.180)\end{array}$ & $\begin{array}{c}0.938 \\
(1.175)\end{array}$ \\
\hline Debt-to-asset ratio & $\begin{array}{l}0.003^{* * * *} \\
(0.001)\end{array}$ & $\begin{array}{l}0.005^{* * * *} \\
(0.001)\end{array}$ & $\begin{array}{c}0.000 \\
(0.009)\end{array}$ \\
\hline Operator age & $\begin{array}{l}0.000^{* * * *} \\
(0.000)\end{array}$ & $\begin{array}{l}0.000^{* * * *} \\
(0.000)\end{array}$ & $\begin{array}{l}0.000^{* * * *} \\
(0.000)\end{array}$ \\
\hline \multicolumn{4}{|l|}{ Elasticities } \\
\hline County household income & $\begin{array}{l}0.122 * * \\
(0.057)\end{array}$ & $\begin{array}{l}0.278^{* * *} * \\
(0.069)\end{array}$ & $\begin{array}{c}-0.359 \\
(0.402)\end{array}$ \\
\hline Fixed costs & $\begin{array}{l}0.103^{* * * *} \\
(0.008)\end{array}$ & $\begin{array}{l}0.208^{* * * *} \\
(0.011)\end{array}$ & $\begin{array}{c}-0.248^{* * * *} \\
(0.050)\end{array}$ \\
\hline Subsidy receipts & $\begin{array}{l}0.018^{* * * *} \\
(0.004)\end{array}$ & $\begin{array}{l}0.034 * * * \\
(0.004)\end{array}$ & $\begin{array}{c}0.004 \\
(0.030)\end{array}$ \\
\hline Off-farm income & $\begin{array}{l}-0.007 * * * \\
(0.002)\end{array}$ & $\begin{array}{l}0.005^{* *} \\
(0.003)\end{array}$ & $\begin{array}{c}-0.064 * * * \\
(0.017)\end{array}$ \\
\hline Conservation payments & $-0.013^{* * *}$ & $-0.008^{* * *}$ & $-0.029 * * *$ \\
\hline$R$-squared & 0.626 & 0.636 & 0.151 \\
\hline
\end{tabular}

gest that their conclusion may be sensitive to year-to-year fluctuations in organic price premiums. We expand on their work by considering a longer time period with temporal fixed effects and adjusting on non-ARMS covariates and location fixed effects. We constrain our analysis to farms who cash rent farmland and consider a simple (log) linear ordinary least squares estimator to compare organic and conventional farms. We cannot adjust for all of the regressors employed in Uematsu and Mishra (2012) because the ARMS did not consistently ask the same questions through our sample period. We transform the majority of our financial variables using IHS (see above) and report results as elasticities, rather than using levels, which makes the interpretation of our results somewhat different. Fi- nally, we model differences in per-acre farm profit rather than total household income, which includes off-farm income. Because of these modeling choices, systemic differences between organic and conventional farms in terms of profitability on owned or rented land, across farm sizes, and other systemic differences could explain why our results do not perfectly match.

The main thrust of our result is consistent with the Uematsu and Mishra (2012) finding that in general, organic farm operations are not significantly better off than their conventional counterparts. Because we normalize our profit measures by acreage rather than considering whole-farm levels, this difference could be the result of systemic differences in scale between organic and conventional farms. To make our 
profit measurement more directly comparable with Uematsu and Mishra (2012), we estimate equation [6] for ROVC in the whole-farm, rather than per-acre, level (not shown here). Doing so does not meaningfully change our result - the correlation between organic status and farm profits generally remains either statistically insignificant, or negative. More broadly, these auxiliary regressions cannot find some reasonable connection in our data between the organic farmers (and the higher rental rates they pay) and observed profits.

\section{Conclusions}

This study provides the first empirical estimate of the relative value of organic farmland. We find greater organic certification at the farm level increases the rental rate paid, such that organic farms pay $26 \%$ more to rent land than do similar conventional farms. This estimate adjusts both for farm-specific characteristics and locational factors that might drive differences in willingness to pay, such as urban proximity, soil characteristics, crop choice, and other factors. Our estimate is not simply the result of broad variation in land prices across space. The prevalence of organic agriculture in places where farmland is expensive, like California, does not explain our result. We also rule out greater per-acre profitability from organic production relative to conventional as a motivation for organic farmers to pay more for land. Consistent with earlier findings from observational data, organic farms do not appear to earn greater peracre accounting profits on average than their conventional counterparts.

Although we employ a relatively large, nationally representative sample of U.S. farms to generate our estimate of the rental value of organic land, our study is limited by the available data. We do not have farm-level panel data that would allow us to adjust for time-invariant farm-specific characteristics, especially farmer-specific management ability and social preferences that might explain observed organic certification decisions and willingness to pay for farmland. Neither do we have a natural experiment or similar exogenous shift in organic conversions. While much observed conversion behavior is likely related to shifts in consumer demand for organic food that are exogenous to farmland supply, we cannot rule out the possibility that certification decisions may be based on factors related to farm input markets. In particular, we cannot adjust for the confounding effect of farm-specific soil quality, which may bias our results in unknown ways. In general, our inability to observe organic transitions at the farm level across time is an impediment to understanding the economics of organic agriculture. $\mathrm{Fu}$ ture data collection efforts should concentrate on observing farmer and landowner behavior before and after organic conversion. Linking farmland price differences to the timing of conversion would be informative about how organic premiums may change across time; for instance, they may dissipate as the market matures.

Our results provide some explanation for the apparent discord between the demand for greater organic crop production and the relatively slow increase in organic acreage. We find that landowners receive some benefit from converting land to organic production in the form of higher cash rental rates. However, this benefit may be small relative to the associated costs. Consider a back-of-the-envelope investment cost-benefit analysis made by the landowner. Suppose they may forgo rental income during the three-year organic transition, ${ }^{13}$ but earn a $26 \%$ premium relative to previous rental rates when the land was farmed conventionally. Such an investment is consistent with an approximately $4.2 \%$ internal rate of return over a 20 -year investment horizon. This return is probably sufficient to induce some growth in organic acres but

${ }^{13}$ The assumption underlying this calculation of a zero rental rate during transition years is strong, but alternative estimates of the cost to landowner to transition farmland are scarce. Organic transition budgets developed by Chase, Delate, and Johanns (2009) for corn-soybean rotations in Iowa are one of few available resources. It is difficult to calculate a transition penalty for a given crop from these budgets, because the crop rotation is assumed to change during the transition process. Moreover, these budgets estimate that returns grow dramatically as a greater proportion of the farm is transitioned to certified organic production. If this is broadly the case, then there may be no transition penalty. However, such dramatically higher projected profits for organic agriculture are inconsistent with observed profits in our data. 
likely excludes those existing landowners or organic farm operators who face a higher cost of capital for investing in organic land conversion. For instance, this rate of return falls below the average interest rate for farm real estate loans in the U.S. Midwest during our sample period (Oppedahl 2018; Kauffman and Kreitman 2019). The transition requirement generates asset fixity in the land market that maintains this small but significant premium. The premium can be thought of as the price the organic farmer must pay to avoid the transition requirement.

Organic conversion does not appear to be an effective means for improving farm profits, at least for those who rent land. This is not to say that organic certification decisions made by current organic farmers are economically irrational or inefficient, only that additional conversion may not be welfare-improving when measured on the basis of accounting profits. The presence of a farmland rental rate premium but not a profit premium also suggests that land and not management ability or operator willingness is the scarce resource preventing larger increases in organic acreage. This is consistent with previous findings of some nonpecuniary benefit of organic production accruing to farm operators. Our results do not attempt to measure or explain operator motives for choosing organic or conventional production directly, but we can infer that organic farmers only earn economic profits to the extent that they own land, not from returns to operations or management activities.

A related explanation for higher organic rental rates lies in tenure security for organic farms on rented land. The asset fixity implied by the rules for organic transition increases the cost of converting farmland. It also may affect the bargaining power held by farm operators in negotiating rental rates with landowners. Because of asset fixity, farmland operators may be willing to pay the organic farmland price premium to rent land to maintain the value of other investments in organic certification and avoid the uncertainty of losing the lease. In work describing the incentives land owners can provide for tenants to use specific sustainable farming methods (e.g., Cox 2010, 2011), tenure security is brought up extensively. Longer-term leases and provisions giving tenants first right of refusal to purchase the land if it is sold are suggested as nudges for tenants to adopt practices that may have long payback periods, similar to organic conversion. For farmers who own land, many of these costs and benefits are internalized. In this way, our work may provide evidence of liquidity and other financial constraints for farmers. One explanation of the persistence of the rental rate premium is that farmers do not have adequate liquid or leverageable assets to purchase land. In the absence of such constraints and assuming competitive markets, land would continue to transition to organic until the economic returns from organic and conventional land were equal.

Existing research on tenure security and the competitiveness of local markets suggests a number of forces that may counter the need to pay for tenure security through higher rental rates. Taylor and Featherstone (2018) find that leases for longer durations are associated with lower lease rates and suggest that a longer tenant-landlord relationship may substitute for part of the monitoring otherwise done by the landlord. Similarly, Kirwan and Roberts (2016) find that farmers capture a significant share of decoupled subsidies and attribute this to farmers' ability to monopsonize local farmland markets. To our knowledge, no research has been done to understand the role of tenure security in organic conversion decisions and rental rate negotiations for organic land. We leave this question for future work; the ARMS does not include data on lease terms or tenure confidence.

Organic agriculture is widely seen as smaller scale and potentially more attractive to new and beginning farmers. Beginning farms are, on average, much smaller than established farms, and access to farmland has been cited as the major barrier to entry into farming (Ahearn 2013). Our finding that rental rates for organic farms are higher than conventional suggests that this barrier may be greater for beginning farmers interested in organic production. That much of the benefit from organic conversion accrues to landowners suggests that organic conversion is unlikely to circumvent the barrier presented by the cost of acquiring land through rental or ownership. 
We can evaluate existing policies and market incentives for adopting organic agriculture in light of the magnitude of our estimated organic farmland price differential. Two examples are subsidies to offset conversion costs, such as the Organic Certification Cost Share Program provided by the USDA and market incentives paid by organic food buyers for production harvested during the three-year organic transition period, such as the QAI Certified Transitional program (Kashi 2016). The first is so small that it seems unlikely to meaningfully change behavior. Market incentives during and after organic conversion may be effective if they are substantial when measured in dollars per acre. However, even large incentives may not be sufficient to induce widespread conversion if organic farm operators reap the benefits of the subsidy but lack the capital to acquire land for conversion.

Our results show a 26\% rental rate premium for organic land, valued at approximately \$29/acre at the average farmland rental rate observed in our data. This premium has been sufficient for at least some certified organic production on rented acres, but many suggest that acreage growth is slow relative to demand for organic foods (e.g., Delbridge et al. 2017). To spur more rapid conversion of U.S. farmland from conventional to organic, organic food demanders must provide greater incentives to both farmers and landowners to transition land to organic. That incentive can either be provided by lowering conversion costs or increasing the return on investment through higher organic product premiums. Our findings suggest that there is room for innovation in both areas.

\section{Acknowledgments}

Fuller and Janzen share lead authorship. The authors thank Jessie Bovay, Tim Delbridge, Iryna Demko, Jennifer Ifft, Andy Rahn, and seminar participants at Montana State University, the University of Illinois at Urbana-Champaign, the 2016 NC-1177 Meeting, the 2017 AAEA Annual Meeting, and the 2017 EAAE Congress for helpful comments on earlier versions of this article. This work was supported by U.S. Department of Agriculture Hatch/Multistate Project 1011710.

\section{References}

Acharya, Avidit, Matthew Blackwell, and Maya Sen. 2016. "Explaining Causal Findings without Bias: Detecting and Assessing Direct Effects." American Political Science Review 110 (3): 512-29. https://doi.org/10.1017/S000305 5416000216.

Ahearn, Mary. 2013. "Beginning Farmers and Ranchers at a Glance." ERS Economic Bulletin 22. http://dx.doi.org/10.2139/ssrn.2266443.

Angrist, Joshua, and Jorn-Steffen Pischke. 2009. Mostly Harmless Econometrics: An Empiricist's Companion. Princeton, NJ: Princeton University Press.

Assunção, Juliano, Arthur Bragança, and Pedro Hemsley. 2019. "Geographic Heterogeneity and Technology Adoption: Evidence from Brazil." Land Economics 95 (4): 599-616. https:// doi.org/10.3368/le.95.4.599.

Bellemare, Marc F., Takaaki Masaki, and Thomas B. Pepinsky. 2017. "Lagged Explanatory Variables and the Estimation of Causal Effect." The Journal of Politics 79 (3): 949-63. https://doi. org/10.1086/690946.

Bellemare, Marc F., and Casey J. Wichman. 2020. "Elasticities and the Inverse Hyperbolic Sine Transformation." The Oxford Bulletin of Economics and Statistics 82 (1): 50-61. https://doi. org/10.1111/obes.12325.

Bigelow, Daniel, Jennifer Ifft, and Todd Kuethe. 2018. "The Compatibility of Farmland Sales and The Compatibility of Farmland Sales and Opinion Survey Data." Working Paper 201806. Ithaca, NY: Cornell University Dyson School. Available at https://dyson.cornell.edu/ wp-content/uploads/sites/5/2019/02/CornellDyson-wp1806.pdf.

Borchers, Allison, Jennifer Ifft, and Todd Kuethe. 2014. "Linking the Price of Agricultural Land to Use Values and Amenities." American Journal of Agricultural Economics 96 (5): 1307-20. https://doi.org/10.1093/ajae/aau041.

Burbidge, John B., Lonnie Magee, and A. Leslie Robb. 1988. "Alternative Transformations to Handle Extreme Values of the Dependent Variable." Journal of the American Statistical Association 83 (401): 123-27. https://doi.org/10.10 80/01621459.1988.10478575.

Chase, Craig, Kathleen Delate, and Ann M. Johanns. 2009. "Making the Transition from Conventional to Organic." Available at https:// www.extension.iastate.edu/agdm/crops/html/ a1-26.html. 
Chouinard, Hayley H., Tobias Paterson, Philip R. Wandschneider, and Adrienne M. Ohler. 2008. "Will Farmers Trade Profits for Stewardship? Heterogeneous Motivations for Farm Practice Selection." Land Economics 84 (1): 66-82. https://doi.org/10.3368/le.84.1.66.

Cox, Edward. 2010. "A Lease-Based Approach to Sustainable Farming, Part I: Farm Tenancy Trends and the Outlook for Sustainability on Rented Land." Drake Journal of Agricultural Law 15: 369-92.

. 2011. "A Lease-Based Approach to Sustainable Farming, Part II: Farm Tenancy Trends and the Outlook for Sustainability on Rented Land." Drake Journal of Agricultural Law, 16: 5-30.

Cranfield, John, Spencer Henson, and James Holliday. 2010. "The Motives, Benefits, and Problems of Conversion to Organic Production." Agriculture and Human Values 27 (3): 291-306. https://doi.org/10.1007/s10460-009-9222-9.

Crowder, David W., and John P. Reganold. 2015. "Financial Competitiveness of Organic Agriculture on a Global Scale." Proceedings of the National Academy of Sciences 112 (24): 761116. https://doi.org/10.1073/pnas.1423674112.

Darnhofer, Ika, Walter Schneeberger, and Bernhard Freyer. 2005."Converting or Not Converting to Organic Farming in Austria: Farmer Types and Their Rationale." Agriculture and Human Values 22 (1): 39-52. https://doi.org/10.1007/ s10460-004-7229-9.

Deaton, Angus. 1985. "Panel Data from Time Series of Cross-Sections." Journal of Econometrics 30 (1-2): 109-26. https://doi.org/10.1016/03044076(85)90134-4.

Delate, Kathleen, Michael Duffy, Craig Chase, Ann Holste, Heather Friedrich, and Noreen Wantate. 2003. "An Economic Comparison of Organic and Conventional Grain Crops in a Long-Term Agroecological Research (LTAR) Site in lowa." American Journal of Alternative Agriculture 18 (2): 59-69. https://doi. org/10.1079/AJAA200235.

Delbridge, Timothy A., Carmen Fernholz, Robert P. King, and William Lazarus. 2013. "A WholeFarm Profitability Analysis of Organic and Conventional Cropping Systems." Agricultural Systems 122: 1-10. https://doi.org/10.1016/j. agsy.2013.07.007.

Delbridge, Timothy A., and Robert P. King. 2016. "Transitioning to Organic Crop Production: A Dynamic Programming Approach." Journal of Agricultural and Resource Econom- ics 41 (3): 481-98. https://doi.org/10.22004/ ag.econ. 246250 .

Delbridge, Timothy A., Robert P. King, Gianna Short, and Kellee James. 2017. "Risk and Red Tape: Barriers to Organic Transition for US Farmers." Choices 32 (4): 1-10.

Economic Research Service. 2017. ARMS Farm Financial and Crop Production Practices: Documentation. Washington, DC: U.S. Department of Agriculture. Available at https://www.ers. usda.gov/data-products/arms-farm-financialand-crop-production-practices/documentation. aspx.

2018. Questionnaires and Manuals. Washington, DC: U.S. Department of Agriculture. Available at https://www.ers.usda.gov/ data-products/arms-farm-financial-and-cropproduction-practices/questionnaires-andmanuals/.

Farmland LP. 2019. Farmland LP Website. Available at http://www.farmlandlp.com/.

Froehlich, Anderson G., Andrea S. S. A. Melo, and Breno Sampaio. 2018. "Comparing the Profitability of Organic and Conventional Production in Family Farming: Empirical Evidence from Brazil." Ecological Economics 150: 307-14. https://doi.org/10.1016/j.ecol econ.2018.04.022.

Goodwin, Barry K., Ashok K. Mishra, and François Ortalo-Magné. 2011. "The Buck Stops Where? The Distribution of Agricultural Subsidies." Technical report. Cambridge, MA: National Bureau of Economic Research. Available at http://www.nber.org/papers/w16693.

Hendricks, Nathan P., Joseph P. Janzen, and Kevin C. Dhuyvetter. 2012. "Subsidy Incidence and Inertia in Farmland Rental Markets: Estimates from a Dynamic Panel." Journal of Agricultural and Resource Economics 37 (3): 361-78. https://doi.org/10.22004/ag.econ.142350.

Imai, Kosuke, Luke Keele, Dustin Tingley, and Teppei Yamamoto. 2011. "Unpacking the Black Box of Causality: Learning about Causal Mechanisms from Experimental and Observational Studies." American Political Science Review 105 (4): 765-89. https://doi.org/10.1017/ S0003055411000414.

Kallas, Zein, Teresa Serra, and José Maria Gil. 2010. 'Farmers' Objectives as Determinants of Organic Farming Adoption: The Case of Catalonian Vineyard Production." Agricultural Economics 41 (5): 409-23. https://doi.org/10.1111/ j.1574-0862.2010.00454.x. 
Karnowski, Steve. 2018. "General Mills, Annie's Mac \& Cheese Tap South Dakota Farm." Business Insider, March 6, 2018. Available at http://www.businessinsider.com/ap-generalmills-annies-mac-cheese-tap-south-dakotafarm-2018-3.

Kashi. 2016. "One Percent is Not Enough: Kashi Champions New Approach to Boost Organic Farmland." Solana Beach, CA: Kashi. Available at https://transitional.kashi.com/en US/news/ press-release.html.

Kauffman, Nathan, and Ty Kreitman. 2019. "As Rates Tick Up, Growth in Operating Loans Boosts Farm Lending." Agricultural Finance Databook. Kansas City, MO: Federal Reserve Bank of Kansas City. Available at https:// www.kansascityfed.org/agriculture/agfinanceupdates/ag-finance-dbk-1-17-2019/.

Khaledi, Mohammad, Simon Weseen, Erin Sawyer, Shon Ferguson, and Richard Gray. 2010. "Factors Influencing Partial and Complete Adoption of Organic Farming Practices in Saskatchewan, Canada." Canadian Journal of Agricultural Economics 58 (1): 37-56. https://doi. org/10.1111/j.1744-7976.2009.01172.x.

Kirwan, Barrett E. 2009. "The Incidence of U.S. Agricultural Subsidies on Farmland Rental Rates." Journal of Political Economy 117 (1): 138-64. https://doi.org/10.1086/598688.

Kirwan, Barrett E., and Michael J. Roberts. 2016. "Who Really Benefits from Agricultural Subsidies? Evidence from Field-Level Data." American Journal of Agricultural Economics 98 (4): 1095-113. https://doi.org/10.1093/ajae/ aaw022.

Krause, Josef, and Ondrej Machek. 2017. "A Comparative Analysis of Organic and Conventional Farmers in the Czech Republic." Agricultural Economics/Zemedelska Ekonomika 63 (1): 1-8. https://doi.org/10.17221/161/2016-AGRIC ECON.

Kuminoff, Nicolai V., Christopher F. Parmeter, and Jaren C. Pope. 2010. "Which Hedonic Models Can We Trust to Recover the Marginal Willingness to Pay for Environmental Amenities?" Journal of Environmental Economics and Management 60 (3): 145-60, https://doi. org/10.1016/j.jeem.2010.06.001.

Kuminoff, Nicolai V., and Ada Wossink. 2010. "Why Isn't More US Farmland Organic?" Journal of Agricultural Economics 61 (2): 240-58. https://doi.org/10.1111/j.1477-9552. 2009.00235.x.
Marasteanu, I. Julia, and Edward C. Jaenicke. 2016. "Hot Spots and Spatial Autocorrelation in Certified Organic Operations in the United States." Agricultural and Resource Economics Review 45 (3): 485-521. https://doi. org/10.1017/age.2016.5.

McBride, William D., and Catherine Greene. 2009. "The Profitability of Organic Soybean Production." Renewable Agriculture and Food Systems 24 (4): 276-84. https://doi.org/10.1017/ S1742170509990147.

McBride, William D., Catherine Greene, Linda Foreman, and Mir Ali. 2015. The Profit Potential of Certified Organic Field Crop Production. Economic Research Service Report No. ERR188. Washington, DC: U.S. Department of Agriculture. Available at https://www.ers.usda. gov/publications/pub-details/?pubid=45383.

Moya, Andrés. 2018. "Violence, Psychological Trauma, and Risk Attitudes: Evidence from Victims of Violence in Colombia." Journal of Development Economics 131 (March): 15-27. https://doi.org/10.1016/j.jdeveco.2017.11.001.

National Agricultural Statistics Service. 2017. Certified Organic Survey 2016 Summary. Washington, DC: U.S. Department of Agriculture. Available at https://www.nass.usda.gov/Publi cations/Todays_Reports/reports/census17.pdf.

Natural Resources Conservation Service. 2017. Web Soil Survey. Washington, DC: U.S. Department of Agriculture. Available at https://web soilsurvey.nrcs.usda.gov/.

Oberholtzer, Lydia, Carolyn Dimitri, and Catherine Greene. 2005. Price Premiums Hold on as US Organic Produce Market Expands. Economic Research Service Report No. VGS-30801. Washington, DC: U.S. Department of Agriculture. Available at https://www.ers.usda.gov/ webdocs/outlooks/39503/29722_vgs30801. pdf?v=3507.9

Oppedahl, David. 2018. "Credit Conditions Historical Data." AgLetter. Chicago: Federal Reserve Bank of Chicago. Available at https://www.chi cagofed.org/research/data/ag-conditions/index.

Organic Trade Association. 2016. State of the Industry. Washington, DC: Organic Trade Association. Available at https://www.ota.com/ resources/market-analysis.

Palmquist, Raymond B. 1989. "Land as a Differentiated Factor of Production: A Hedonic Model and Its Implications for Welfare Measurement." Land Economics 65 (1): 23-28. https://doi. org/10.2307/3146260. 
Pearl, Judea. 2001.'Direct and Indirect Effects." In Proceedings of the Seventeenth Conference on Uncertainty in Artificial Intelligence. 411-20. San Francisco, CA: Morgan Kaufman. Available at https://ftp.cs.ucla.edu/pub/stat_ser/ R273-U.pdf.

Peterson, Hikaru Hanawa, Andrew Barkley, Adriana Chacón-Cascante, and Terry L. Kastens. 2012. "The Motivation for Organic Grain Farming in the United States: Profits, Lifestyle, or the Environment?" Journal of Agricultural and Applied Economics 44 (2): 137-55. https://doi. org/10.1017/S1074070800000237.

Plantinga, Andrew J., Ruben N. Lubowski, and Robert N. Stavins. 2002. "The Effects of Potential Land Development on Agricultural Land Prices." Journal of Urban Economics 52 (3): 561-81. https://doi.org/10.1016/S00941190(02)00503-X.

Roberts, Michael J., Barrett Kirwan, and Jeffrey Hopkins. 2003. "The Incidence of Government Program Payments on Agricultural Land Rents: The Challenges of Identification." American Journal of Agricultural Economics 85 (3): 76269. https://doi.org/10.1111/1467-8276.00481.

Severen, Christopher, Christopher Costello, and Olivier Deschênes. 2018. "A Forward-Looking Ricardian Approach: Do Land Markets Capitalize Climate Change Forecasts?" Journal of Environmental Economics and Management 89 (May): 235-54. https://doi.org/10. 1016/j. jeem.2018.03.009.

Sierra, Luis, Karen Klonsky, Ron Strochlic, Sonja Brodt, and Richard Molinar. 2008. Factors As- sociated with Deregistration Among Organic Farmers in California. Davis, CA: California Institute for Rural Studies. Available at http:// www.cirsinc.org/publications/category/9-foodsystems.

Taylor, Mykel R., and Allen M. Featherstone. 2018. "The Value of Social Capital in Farmland Leasing Relationships." Agricultural Finance Review 78 (4): 489-96. https://doi.org/10.1108/ AFR-08-2017-0067.

Trujillo-Barrera, Andres, Joost M. E. Pennings, and Dianne Hofenk. 2016. "Understanding Producers' Motives for Adopting Sustainable Practices: The Role of Expected Rewards, Risk Perception and Risk Tolerance." European Review of Agricultural Economics 43 (3): 359-82. https://doi.org/10.1093/erae/jbv038.

Uematsu, Hiroki, and Ashok K. Mishra. 2012. "Organic Farmers or Conventional Farmers: Where's the Money?" Ecological Economics 78 (June): 55-62. https://doi.org/10.1016/j. ecolecon.2012.03.013.

Veldstra, Michael D., Corinne E. Alexander, and Maria I. Marshall. 2014. "To Certify or Not to Certify? Separating the Organic Production and Certification Decisions." Food Policy 49 (2): 429-36. https://doi.org/10.1016/j.food pol.2014.05.010.

Weber, Jeremy G., Nigel Key, and Erik O'Donoghue. 2016. "Does Federal Crop Insurance Make Environmental Externalities from Agriculture Worse?" Journal of the Association of Environmental and Resource Economists 3 (3): 707-42. https://doi.org/10.1086/687549. 